OECDpublishing

\title{
TAX POLICIES FOR INCLUSIVE
}

GROWTH: PRESCRIPTION

\section{VERSUS PRACTICE}

OECD ECONOMIC POLICY PAPER

December 2018 No. 24 
Economic Policy Paper No. 24

\section{Tax Policies for Inclusive Growth: Prescription versus Practice}

\section{This paper has been prepared by: Robert Hagemann}

Authorised for publication by Laurence Boone

Chief Economist and G20 Finance Deputy

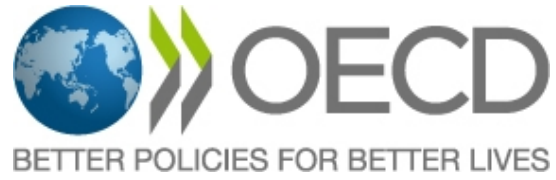


The OECD Economic Policy Paper Series is published on the responsibility of the Secretary-General of the OECD. The opinions expressed and arguments employed herein do not necessarily reflect the official views of the Organisation or of the governments of its member countries.

Series: OECD Economic Policy Papers

SSN 2226583X

The statistical data for Israel are supplied by and under the responsibility of the relevant Israeli authorities. The use of such data by the OECD is without prejudice to the status of the Golan Heights, East Jerusalem and Israeli settlements in the West Bank under the terms of international law.

On 3 May 2018, the OECD Council invited Lithuania to become a Member. At the time of preparation, the deposit of Lithuania's instrument of accession to the OECD Convention was pending and therefore Lithuania does not appear in the list of OECD Members and is not included in the OECD zone aggregates.

On 25 May 2018, the OECD Council invited Colombia to become a Member. At the time of preparation, the deposit of Colombia's instrument of accession to the OECD Convention was pending and therefore Colombia does not appear in the list of OECD Members and is not included in the OECD zone aggregates.

This document and any map included herein are without prejudice to the status of or sovereignty over any territory, to the delimitation of international frontiers and boundaries and to the name of any territory, city or area.

You can copy, download or print OECD content for your own use, and you can include excerpts from OECD publications, databases and multimedia products in your own documents, presentations, blogs, websites and teaching materials, provided that suitable acknowledgment of OECD as source and copyright owner is given. All requests for public or commercial use and translation rights should be submitted to rights@oecd.org. Requests for permission to photocopy portions of this material for public or commercial use shall be addressed directly to the Copyright Clearance Center (CCC) at info@copyright.com or the Centre français d'exploitation du droit de copie (CFC) at contact@cfcopies.com. 
This OECD Economic Policy Paper combines insights from cross-country research work and country experiences drawn from OECD Economic Surveys. It covers tax chapters of Economic Surveys for Australia, Belgium, Canada, Colombia, the Czech Republic, Denmark, Estonia, Finland, France, Germany, India, Indonesia, Israel, Japan, Korea, Norway, Poland, Portugal, Sweden, Switzerland and Turkey. Cross-country empirical research papers on taxation by the Economics Department include:

Johansson, Å., C. Heady, J. Arnold, B. Brys and L. Vartia (2008), "Taxation and Economic Growth", OECD Economics Department Working Papers, No. 620, OECD Publishing. http://dx.doi.org/10.1787/241216205486

Akgun, O., B. Cournède and J-M. Fournier (2017), "The Effects of the Tax Mix on Inequality and Growth", OECD Economics Department Working Papers, No. 1447, OECD Publishing, Paris. http://dx.doi.org/10.1787/c57eaa14-en

Akgun, O., D. Bartolini and B. Cournède (2017), "The Capacity of Governments to Raise Taxes", OECD Economics Department Working Papers, No. 1407, OECD Publishing, Paris.

https://doi.org/10.1787/6bee2df9-en

The work by Robert Hagemann, a consultant for the OECD, was supervised by Boris Cournéde and Peter Hoeller. The author would like to thank Boris Cournéde, Claude Giorno, Peter Hoeller, Luiz de Mello, Jon Pareliussen (Economics Department) and Bert Brys, Luisa Dressler and Tibor Hanappi (Centre for Tax Policy and Administration) as well as Ireland's delegate to Working Party No. 1 of the Economic Policy Committee for their comments and suggestions. He also thanks Celia Rutkoski for excellent editorial assistance.

The author wishes to acknowledge his gratefulness to the late Debra Bloch for her valuable statistical assistance. 


\section{Table of contents}

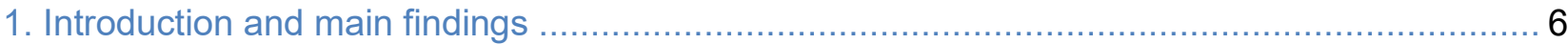

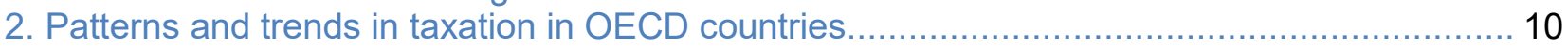

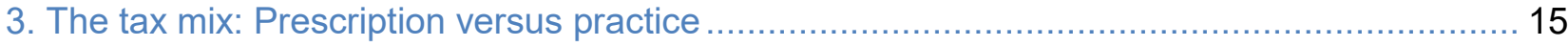

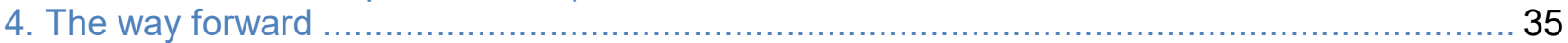

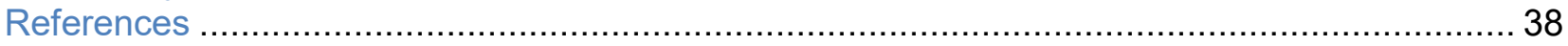

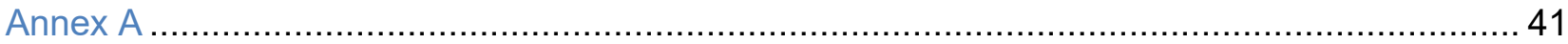

Tables

1. Summary of estimated effects of tax reforms on inequality and output ........................ 8

A1. Tax reform recommendations in OECD Economic Surveys .................................... 45

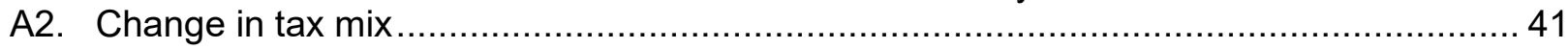

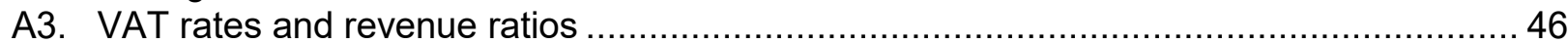

Figures

1. The equalizing impact of taxes and transfers in OECD countries.............................. 7

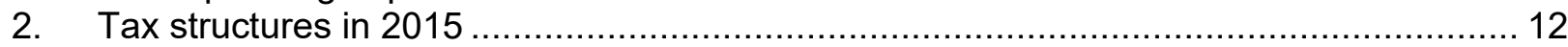

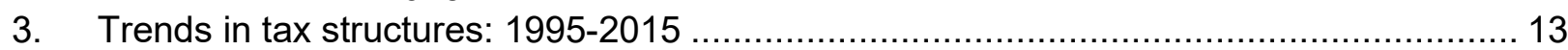

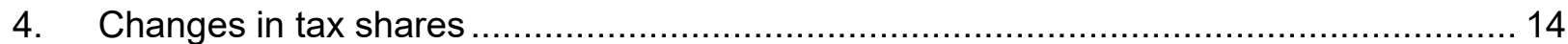

5. Change in overall and immovable property taxes ................................................. 17

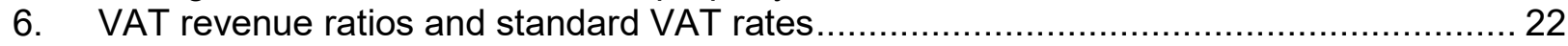

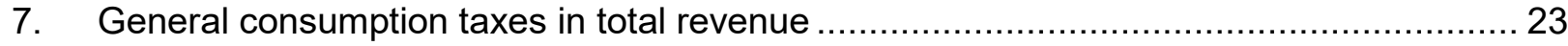

8. Revenues from environmentally-related taxes .................................................... 26

9. Average PIT rate and tax wedge progression across the OECD for 6 household types, by income level.

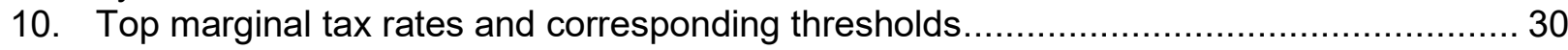

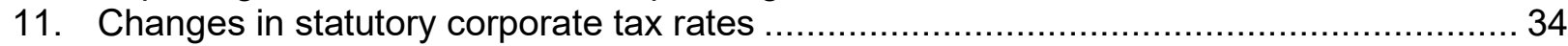

\section{Boxes}

Box 1. The role of transfers in inclusive growth strategies .......................................... 6

Box 2. Revenue allocation across levels of government ............................................ 11

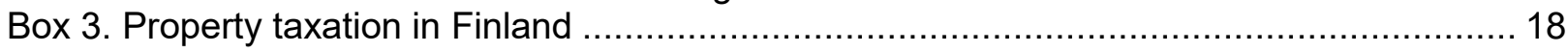

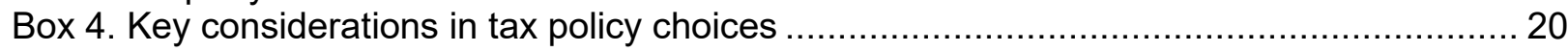

Box 5. Country examples of efforts to change the tax mix.............................................. 36 


\section{Abstract \\ Tax Policies for Inclusive Growth: Prescription versus Practice}

Against a backdrop of the widening income distribution in most countries, OECD governments need to formulate policies that support sustainable and inclusive economic growth. Tax policies play a crucial role in this endeavour. Both tax theory and mounting empirical evidence suggest that many countries could achieve both higher and more broadly shared income growth. Many countries, however, seem hesitant to fundamentally restructure their tax systems to achieve higher and more inclusive growth. This reluctance begs a key question: Why forego tax policy reforms that hold the obvious promise of win-win outcomes of both higher and more inclusive growth? To offer some concrete answers to this question, this paper reports the findings of a synthesis of cross-country empirical work on the ranking (in terms of efficiency and distributional impact) of major tax instruments on the one hand, and, on the other, country-specific tax policy assessments reported in several dozen OECD Economic Surveys since 2008. The paper identifies a wide range of factors, some common to many countries and some country-specific, that prevent governments from adopting tax structures more favourable to inclusive growth. These include political economy forces, legal obstacles, administrative constraints, and intergovernmental fiscal arrangements.

Keywords: Tax policy, public finance, inclusive growth

JEL classification: H2; H3; I3

$$
* * * * *
$$

\section{Résumé}

\section{Les politiques fiscales en faveur de la croissance inclusive : de la théorie à la pratique}

Face à des écarts de revenu qui se creusent dans la plupart des pays, les autorités des pays de I'OCDE se doivent d'élaborer des politiques publiques qui soient porteuses d'une croissance économique durable et inclusive. Les politiques fiscales jouent un rôle crucial à cet égard. La théorie fiscale, mais aussi les faits empiriques observés, de plus en plus nombreux, laissent penser que bon nombre de pays pourraient parvenir à une croissance des revenus à la fois plus forte et mieux partagée. Or, il semble qu'ils hésitent, pour un grand nombre d'entre eux, à restructurer de fond en comble leur fiscalité pour atteindre cet objectif d'une croissance plus soutenue et plus inclusive. Cette réticence suscite une interrogation fondamentale : pourquoi se priver de réformes fiscales de toute évidence prometteuses d'un bilan gagnant-gagnant en termes de taux de croissance et d'inclusivité ? Dans le but d'apporter quelques éléments de réponse concrets, cette étude présente les résultats d'une synthèse entre d'une part, diverses analyses empiriques internationales qui établissent un classement (en fonction de leur efficience et de leur impact sur la distribution des revenus) des principaux instruments de la fiscalité et, d'autre part, les évaluations des politiques fiscales nationales telles que présentées dans des dizaines d'Études économiques de l'OCDE depuis 2008. Cette étude recense un grand nombre de facteurs, tantôt communs à de nombreux pays, tantôt plus spécifiques, qui empêchent les pouvoirs publics d'adopter des structures fiscales plus propices à la croissance inclusive, et notamment : l'économie politique et les forces en jeu en la matière, les obstacles juridiques, les contraintes administratives et les conventions fiscales intergouvernementales.

Mots-clefs : Politique fiscale, finances publiques, croissance inclusive

Classification JEL : H2; H3; 13 


\section{Tax Policies for Inclusive Growth: Prescription versus Practice}

\section{Introduction and main findings}

Governments raise revenue to finance public spending, but in doing so they must balance two potentially undesirable aspects of taxation. First, absent lump sum taxation, taxes affect relative prices, and the resulting distortions cause economic outcomes to differ from what they would otherwise be. Some outcomes are desirable, such as when taxes discourage welfarereducing behaviour (for example, pollution). However, most taxes have, to varying degrees, harmful effects on output. Second, due to the uneven distribution of various tax bases, some taxes can be regressive, that is, they may be a greater burden on low-income households than on those with higher income. At the same time, even if a tax is regressive, but good for growth, its increase is compatible with equity objectives, given the availability in most OECD countries of cash and in-kind transfers targeted at low-income households.

The widening of the income distribution across the OECD countries during the past several decades has led many governments to focus on policies, including tax policies, that are more favourable to inclusive growth, i.e. that minimize the adverse impacts on growth, while ensuring that the benefits of growth are broadly shared. Government transfers also play a role in ensuring inclusiveness, and the impacts of taxes and transfers have recently been reviewed by the OECD Secretariat (Box 1). Much cross-country work has been undertaken on the nexus between taxation and inclusive growth, including at the OECD, to quantify the relative impacts of different taxes on growth and income inequality. A key finding emerging from the research on the former (Johansson et al., 2008, Arnold, 2008, and Arnold et al., 2011) is a ranking of taxes based on their comparative harmful effects on growth. Consensus has steadily grown on the following ranking of taxes, from least to most harmful to economic growth: recurrent taxes on immovable property, consumption taxes (including environmentally-related levies), personal income taxes, and corporate income taxes. However, some taxes are more regressive than others, leaving policymakers to struggle with growth-equity trade-offs.

\section{Box 1. The role of transfers in inclusive growth strategies}

Transfers, whether in cash or in kind, play an important role in reducing inequality and, therefore, in improving the inclusiveness of growth. The impact of taxes and transfers on inequality in OECD countries has recently been assessed by the OECD (Causa and Hermansen, 2018). Although the combined role of taxes and transfers in reducing inequality has declined over the past several decades in most OECD countries, raising concerns about their reduced impact, they continue to be an important policy lever (see chart below). OECD countries provide a little over $4 \%$ of GDP in cash transfers to the working-age population, to which can be added social spending (e.g. health, education, etc.). Taxes and transfers together reduce inequality by about $25 \%$ on average across the OECD, ranging from $5 \%$ in Chile to $40 \%$ in Ireland. This compares to a mid-1990s average of roughly $33 \%$ in 15 OECD countries (Australia, Canada, Czech Republic, Denmark, Finland, France, Germany, Israel, Italy, the Netherlands, New Zealand, Norway, Sweden, United Kingdom and the United States). This was due by and large to reductions in cash transfers, especially for those without work, although some of this decline was offset by increases in in-kind transfers such as health care. There are exceptions, such as Ireland, where marked increases in cash transfers to the poor substantially increased redistribution (Callan, Bercholz, \& Walsh, 2017). 
Box 1. The role of transfers in inclusive growth strategies (cont.)

Figure 1. The equalizing impact of taxes and transfers in OECD countries

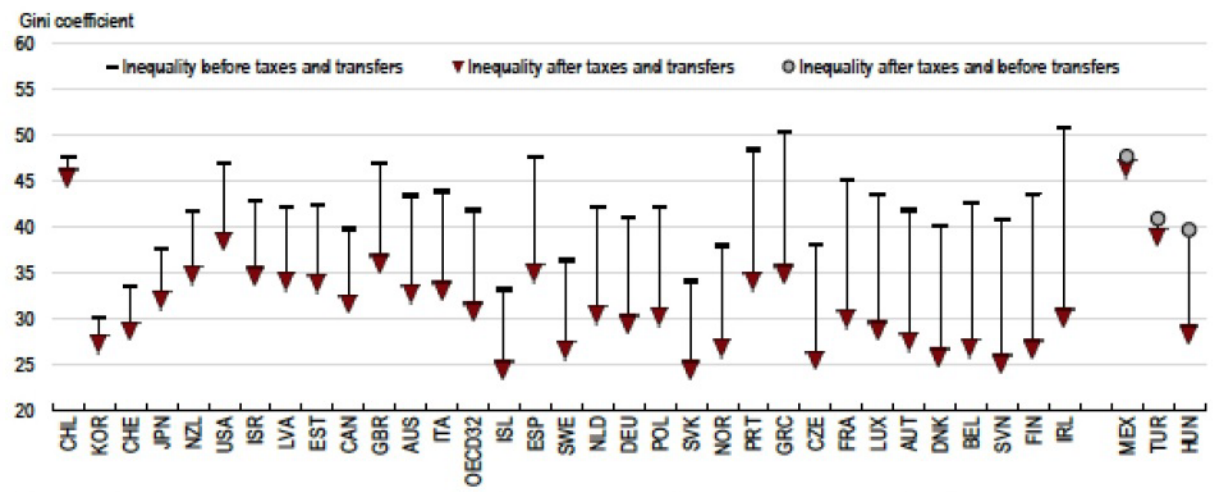

Note: The Gini index measures the extent to which the distribution of incomes among households deviates from a perfectly equal distribution. A value of zero represents perfect equality and a value of 100 extreme inequality. Redistribution is measured by the difference between the Gini coefficient before personal income taxes and transfers (market incomes) and the Gini coefficient after taxes and transfers (disposable incomes) in per cent of the Gini coefficient before taxes and transfers. For Hungary, Mexico and Turkey household incomes are only available net of personal income taxes, implying that inequality can only be measured after taxes and before transfers. The three countries are not included in the OECD average. Working-age populations include all individuals aged 18-65. Data refer to 2012 for Japan; 2015 for Chile, Finland, Israel, Korea, the Netherlands, the United Kingdom and the United States; and 2014 for the rest.

Source: OECD Social and Welfare Statistics (database), https://doi.org/10.1787/data-00654-en.

Correspondingly, the decline in redistribution is in part explained by an increased prevalence of welfare programmes founded on work-related incentives such as a refundable earned-income tax credit. In other words, countries appear generally to have given increased emphasis to efficiency considerations in formulating low-income support programmes. Combined with reductions in the size of cash transfers, such increased targeting might at first glance be interpreted as resulting from an inevitable trade-off of equity for efficiency. A more complete perspective, however, recognizes the need for tax and transfer reforms to be shaped complementarily with other instruments to address the uneven distribution of market income, particularly where the widening of the income distribution is due to stagnating low incomes (e.g. skills mismatch, trade-related job losses, etc.).

More recent cross-country empirical work by the OECD has furthered the earlier analyses to take into explicit account the joint impacts of taxes on growth and inequality (Akgun et al., 2017). This cross-country analysis estimates the effects of shifts in tax structures on both output and the distribution of household income for a given (i.e. unchanged) size of government. Specifically, the framework takes into account not only the direct effects of tax policies on the distribution of disposable income, but also the indirect distributional effects of those policies as they impact the level of output and the pattern of changes in market and disposable income they engender. The key findings are shown in Table 1. 
Table 1. Summary of estimated effects of tax reforms on inequality and output

Simulated net effects of tax shifts that accompany the change under consideration by proportional adjustments of other taxes to keep government revenue fixed

\begin{tabular}{|c|c|c|c|c|}
\hline $\begin{array}{l}\text { Keeping overall revenue constant, } \\
\text { effect of tax reforms that: }{ }^{1}\end{array}$ & $\begin{array}{l}\text { Equality: } \\
\text { Poor/rich² }\end{array}$ & $\begin{array}{l}\text { Average } \\
\text { output }^{3}\end{array}$ & $\begin{array}{c}\text { Income } e^{4} \text { of } \\
\text { the poor }\end{array}$ & $\begin{array}{c}\text { Income of } \\
\text { the rich }\end{array}$ \\
\hline Lower tax wedge on upper-middle incomes & (:) & ;) & ;) & $(-)$ \\
\hline Lower tax wedge on lower-middle incomes & (:) & (:) & $(-)$ & ;: \\
\hline Reduce the effective CIT rate ${ }^{5}$ & n.s. & (:) & $(\ddot{)}$ & $(\dot{)}$ \\
\hline Change the standard VAT rate ${ }^{5}$ & n.s. & n.s. & n.s. & n.s. \\
\hline Make greater use of environmental taxes & $:$ & n.s. & $:$ & (:) \\
\hline Raise recurrent immovable property taxes & n.s. & $\odot$ & (:) & (; \\
\hline Raise inheritance taxes & (;) & ;) & $(\ddot{)}$ & ;) \\
\hline Cut taxes on net wealth & $:$ & (:) & (:) & $(-)$ \\
\hline
\end{tabular}

1. The sign of the change in taxation (increase or decrease) is chosen so that the average output effect is positive, to facilitate comparisons.

2. For a given instrument, the size of smileys reflects the relative size of the effect across the different outcomes. The equality effect reflects the difference between the effects on the poor and the effect on the rich within the working-age population. The poor are defined as the bottom income quintile and the rich as the top one.

3. Output results relate to long-term GDP per capita.

4. Income refers to the long-term levels of disposable income for households where the reference person is of working-age, adjusted by size.

5. CIT is corporate income tax and VAT is value added tax.

Source: Akgun et al. (2017), "The Effects of the Tax Mix on Inequality and Growth", OECD Economics Department Working Papers, No. 1447, OECD Publishing, Paris, http://dx.doi.org/10.1787/c57eaa14-en.

While cross-country empirical analyses can provide policy guidance on broad tax categories, they are inherently constrained by required aggregation. OECD country surveys are a potentially rich source of country-specific experiences on which to draw practical lessons for best practices in tax policy formulation. This paper seeks to bridge the cross-country work and country-specific reviews contained in a large sample of OECD Economic Surveys. Since 2008, the OECD Secretariat has examined the tax policies of more than twenty countries. The countries and policy recommendations are presented in Annex Table 1. Given the framework that emerges from cross-country analyses, what can a more "granular" inspection of country-specific experiences offer about the formulation of tax policies more favourable to inclusive growth? What obstacles or constraints tend to prevent governments from reforming tax systems to achieve inclusive growth? What lessons regarding necessary preconditions can be drawn from countries' particular circumstances?

The principal lessons learned from the review include:

- Governments are generally hesitant to take more than incremental steps to implement tax measures that could increase sustainable per capita income growth while also securing a less uneven distribution of that growth across income levels. Even revenueneutral tax reforms inevitably create losers and winners. Absent budgetary resources to compensate losers, resistance to reducing tax preferences in most major tax areas can be strong. More generally, opposition to tax reform is due to a range of factors, including concerns about distributional impacts, political economy forces such as lobbying, institutional constraints, administrative limitations, etc. 
- There are significant obstacles to increasing the share of recurring immovable property taxes:

- The tax revenues tend not to accrue to central governments but rather to sub-central governments, which limits the ability of central governments in most countries to set tax rates and bases.

- Assessments of property values are in many countries significantly out-of-date.

- Tilting the mix of general government tax revenue toward greater taxation of immovable property would require in most countries a demanding holistic approach that would take into account not only direct taxes on immovable property, but also real-estate taxation under both VAT and the income tax, as well as intergovernmental tax assignment challenges.

- With standard VAT rates already relatively high in most countries, increasing the share of revenue from general consumption taxes requires base broadening and elimination of reduced rates:

- Even though reduced VAT rates and/or exemptions for selected goods and services and/or sectors of the economy are poorly targeted and are an ineffective means of redistribution, governments seem reluctant or hesitant to remove such provisions.

- Greater transparency and better targeting of any warranted compensation payments for regressive taxes, notably VAT and other indirect taxes, could be achieved using means-tested cash and/or in-kind benefits, but governments tend to be very cautious in adopting such measures.

- A large portion of the tax base is left unexploited, resulting in higher tax rates than otherwise would be needed.

- Governments are becoming more attentive to the use of tax instruments to help address environmental concerns, and tax instruments are widely used to help deter environmentally harmful behaviour and internalise pollution costs. Beyond direct regulatory means of limiting or reducing pollution, mechanisms include excise taxes on fossil fuel products and derivatives, carbon taxes, tradable emissions permits and road tolls (which also help reduce congestion). Governments have tended to be cautious about ratcheting up such taxes and fees in large part due to their perceived regressivity and the absence of adequate compensation schemes.

- Widespread efforts are made to reduce marginal effective income tax rates at both the lower and upper end of the income distribution, but are constrained by:

- High social security contribution rates. Where cuts in social security contribution rates are warranted (for example, when the contribution-benefits linkage is weak), substitute financing would be needed, which would further weaken the contributionbenefit linkage.

- High effective tax rates at low-income levels due to the clawback of social benefits require welfare programme reforms that governments, for budgetary reasons, may be reluctant to adopt. 
- Reducing effective tax rates on working spouses can require not only changes to key income tax parameters but also the definition of the tax unit, namely shifting taxation from the household to the individual income earner, which can be difficult to implement.

- Base-broadening (such as by reducing the scope and/or generosity of tax deductions) could potentially finance further lowering of statutory rates while maintaining or even increasing progressivity at upper-income levels, but political roadblocks often stifle such initiatives.

- Corporate tax base-broadening measures (by reducing tax expenditures) have facilitated cutting marginal and average effective tax rates in most countries. Further reforms remain feasible in many countries, but:

- In those countries where corporate tax rates have been reduced considerably, further cuts are likely a lower priority than addressing other tax mix changes favourable to inclusive growth.

- In some countries, corporations are subject to additional taxes determined by rates and bases set by sub-central governments that are not inclined to change the tax mix.

- There is strong resistance to the elimination of preferential tax treatment of small and medium-sized enterprises despite the recognition that, as is the case for any targeted preference, these reduce revenues, oblige higher rates for larger enterprises, and tend to incentivise small enterprises not to expand.

The paper is organised as follows. Section 2 provides a brief overview of revenue developments over the past couple of decades. Section 3 reviews the tax policies pursued by governments, and the constraints or obstacles that were encountered. The paper concludes with a brief note on the way forward.

\section{Patterns and trends in taxation in OECD countries}

The level of taxation, as measured by the percentage of total general government tax revenue in GDP, varies across countries as a reflection of differences in the level of government outlays. For the OECD as a whole, the tax to GDP ratio rose from $28.6 \%$ of GDP in 1975 to $34 \%$ in 2015. The tax mix also varies, reflecting a host of determinants, including among others the structure and openness of the economy, inter-governmental arrangements (e.g. unitary versus federal structure) (Box 2), the institutional capacities of the national and sub-national government administrations, and collective attitudes toward income redistribution and the use of progressive taxation. 


\section{Box 2. Revenue allocation across levels of government}

Not all revenue is collected by the central government. Sub-central entities generate their own revenues, to varying degrees. Among the eight OECD countries with a federal structure (Australia, Austria, Belgium, Canada, Germany, Mexico, Switzerland and the United States), central governments received $54 \%$ of total tax revenues in 2015. The remaining $46 \%$ was shared among social security funds $(21.1 \%)$, local governments $(17.1 \%)$ and state or regional governments $(7.5 \%)$. Spain is a non-federal but highly decentralised country, where two fifths of revenue was collected by the central government in 2015 , followed by a third accruing to social security funds and the remainder to state and local governments. Other OECD countries have a unitary structure in which the central government collected on average $63.5 \%$ of tax revenue in 2015 , and the rest was split $2 / 3-1 / 3$ between social security funds and local governments, respectively.

The tax mix varies substantially between central and sub-central governments. Central governments rely substantially more on income (including social security contributions and other social insurance payments) and consumption taxes than do lower levels of government. The United States is somewhat exceptional, however, as taxes on goods and services account for less than $7 \%$ of federal revenues. In most countries, revenue from property taxes is a substantially more important share of revenue at sub-national levels of government (normally local governments), up to $90 \%$ in Greece, Ireland, Israel, and the United Kingdom). ${ }^{1}$

1. There is actually much variation in the structure of tax revenue at the sub-national level of government. The reader is referred to Table 1.9 of Revenue Statistics, 1965-2015 (OECD, 2017).

\subsection{Tax structures}

Although there are notable differences across countries in the structure of taxation, some common patterns exist. All governments raise revenue from a mix of taxes, fees and a variety of non-tax sources of income. The OECD identiffies six categories of taxation: i) Taxes on personal income; ii) Social security contributions; iii) Corporate income taxes; iv) Consumption taxes; v) Property taxes; and vi) other taxes. Across the OECD, countries tend to fall into one of three groups based on the composition of their tax systems (Figure 2). On average, OECD countries collected slightly over a third of revenue from income taxes (personal and corporate) in 2015, reflecting the importance of such taxes in 17 countries. In many of these countries, taxes on goods and services also figure prominently, as do social security contributions. The remaining countries are evenly split into two groups, in both of which social security and taxes on goods and services are dominant. A notable feature of OECD tax structures is the generally small role of property taxes in financing general government spending, averaging just below $2 \%$ of GDP in 2015 , or $5.8 \%$ of tax revenues. 
Figure 2. Tax structures in 2015

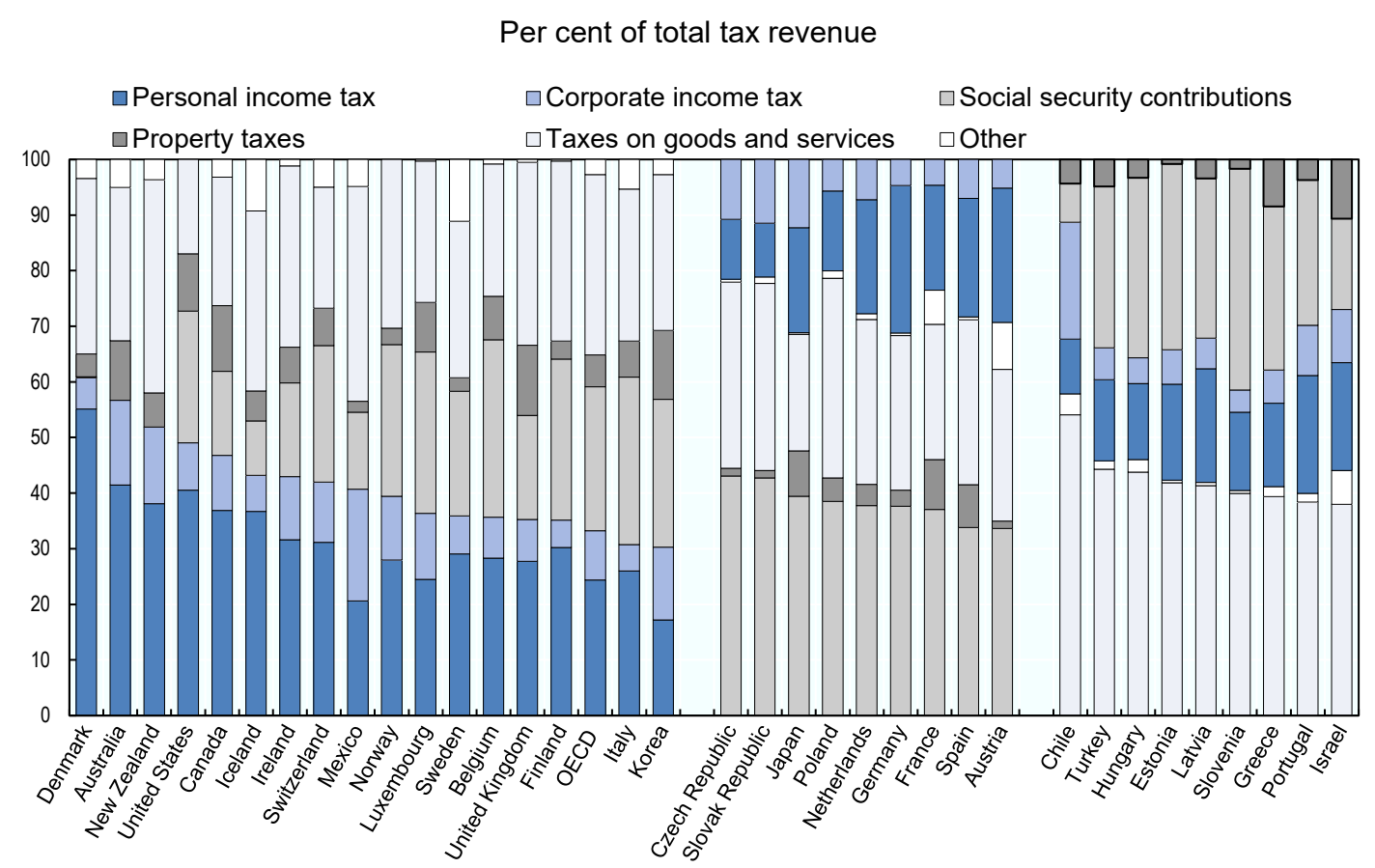

Source: OECD (2017), Revenue Statistics: 1965-2016, OECD Publishing, Paris, http://dx.doi.org/10.1787/9789264283183-en.

\subsection{Changes since the mid-1990s}

The broad stability of OECD countries' tax structures during the past few decades masks some underlying changes (Figure 3). From the mid-1990s to 2015, on average in the OECD corporate tax receipts remained under $10 \%$ of total tax revenue (under $3 \%$ of GDP) but for a spike during 2005-08. A general decline of the share of personal income taxes was offset by an increase in the importance of social security contributions. The share of value added taxes continued an upward trend begun in the mid-1960s, mirrored by a sustained decline of other taxes on goods and services, mostly specific taxes. The relative importance of property taxes in general government revenue has remained remarkably unchanged. 
Figure 3. Trends in tax structures: 1995-2015

Per cent of total tax revenue
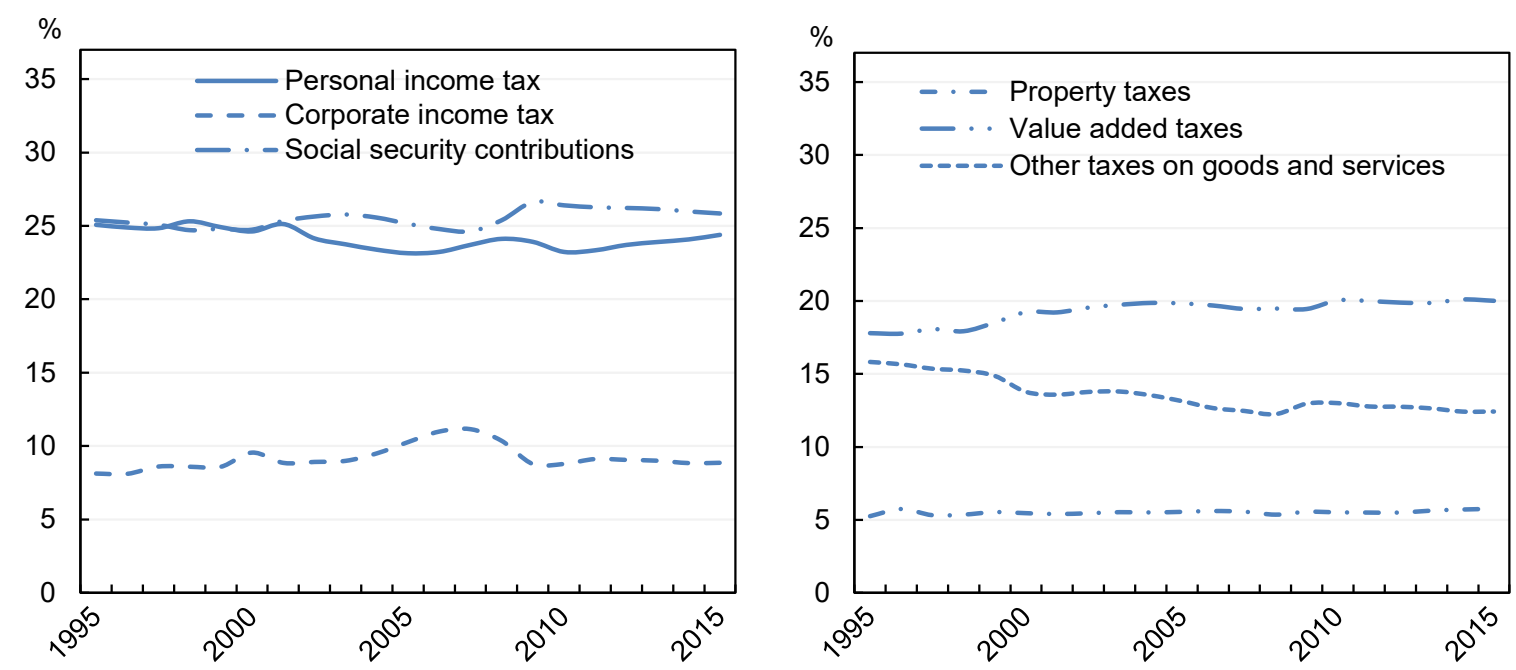

Source: OECD (2017), Revenue Statistics: 1965-2016, OECD Publishing, Paris, http://dx.doi.org/10.1787/9789264283183-en.

Figure 4 shows the share of major tax categories in total general government tax revenue in 1995 and 2015 in each country (Data are shown in Annex Table 2.) In virtually all countries, the share of each tax in most categories changed by less than 10 percentage points, and most changes were less than 6 percentage points. The exceptions were Iceland, where consumption taxes declined sharply as a share of tax revenues; Korea, where there was a shift in the mix away from consumption taxation toward social security contributions; and Turkey, which witnessed a substantial increase in the share of social security contributions. 
Figure 4. Changes in tax shares

Panel A. Personal income taxes, as per cent of total tax revenues

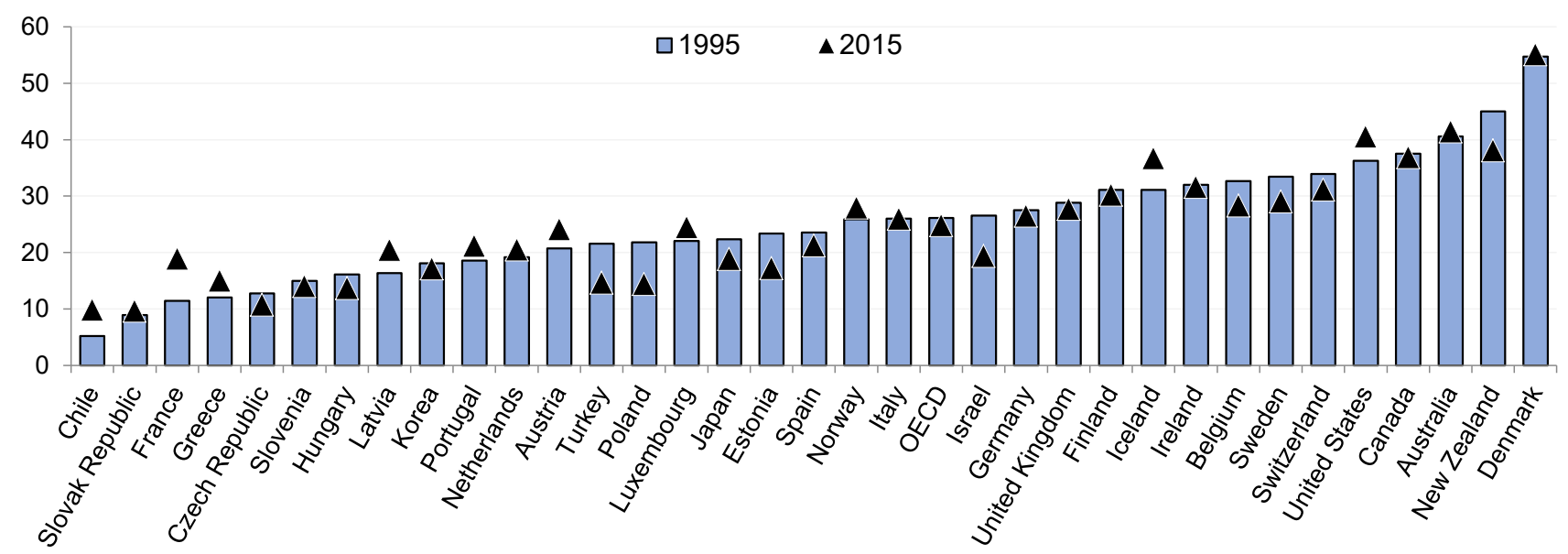

Panel B. Social security contributions, as per cent of total tax revenues

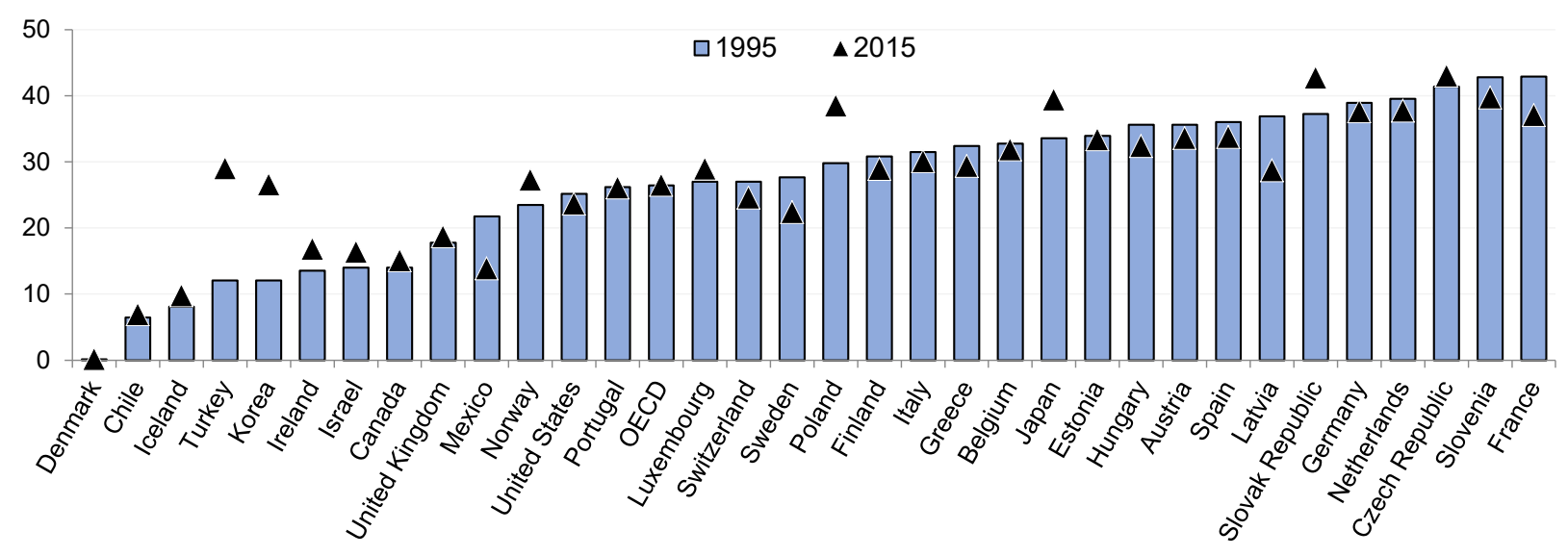

Panel C. Corporate income taxes, as per cent of total tax revenues

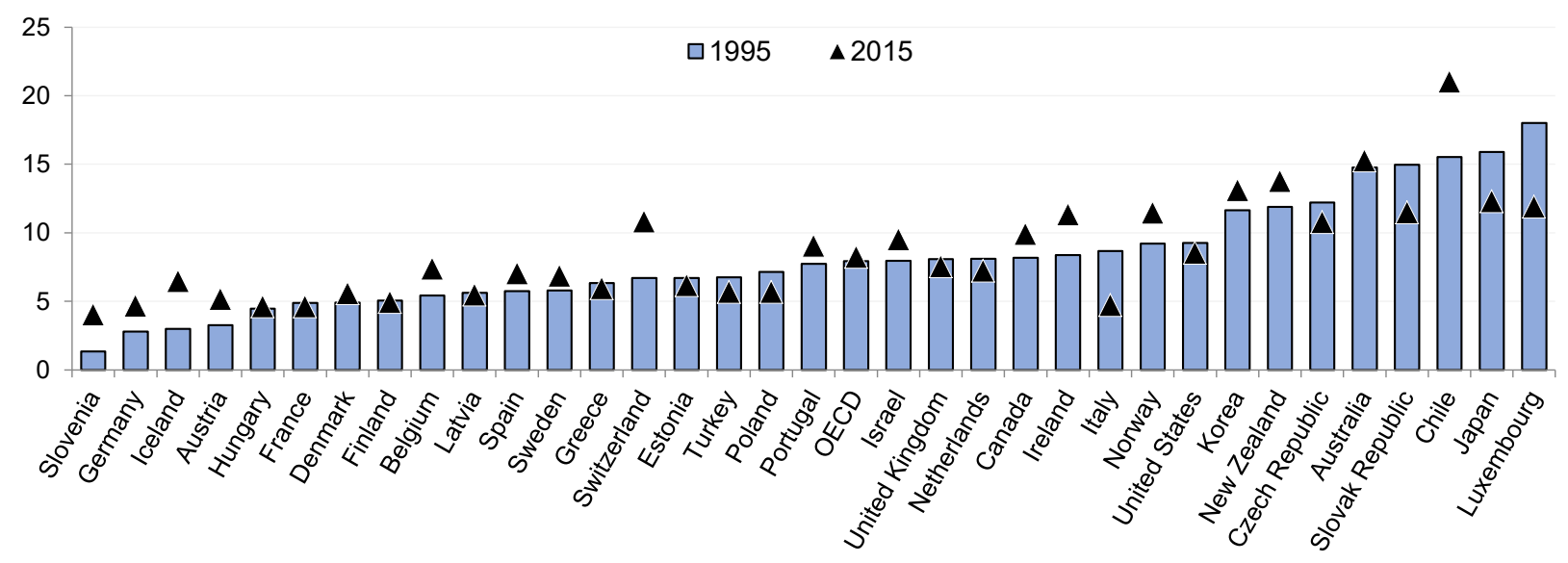


Figure 4. Changes in tax shares (cont.)

Panel D. Taxes on goods and services, as per cent of total tax revenues

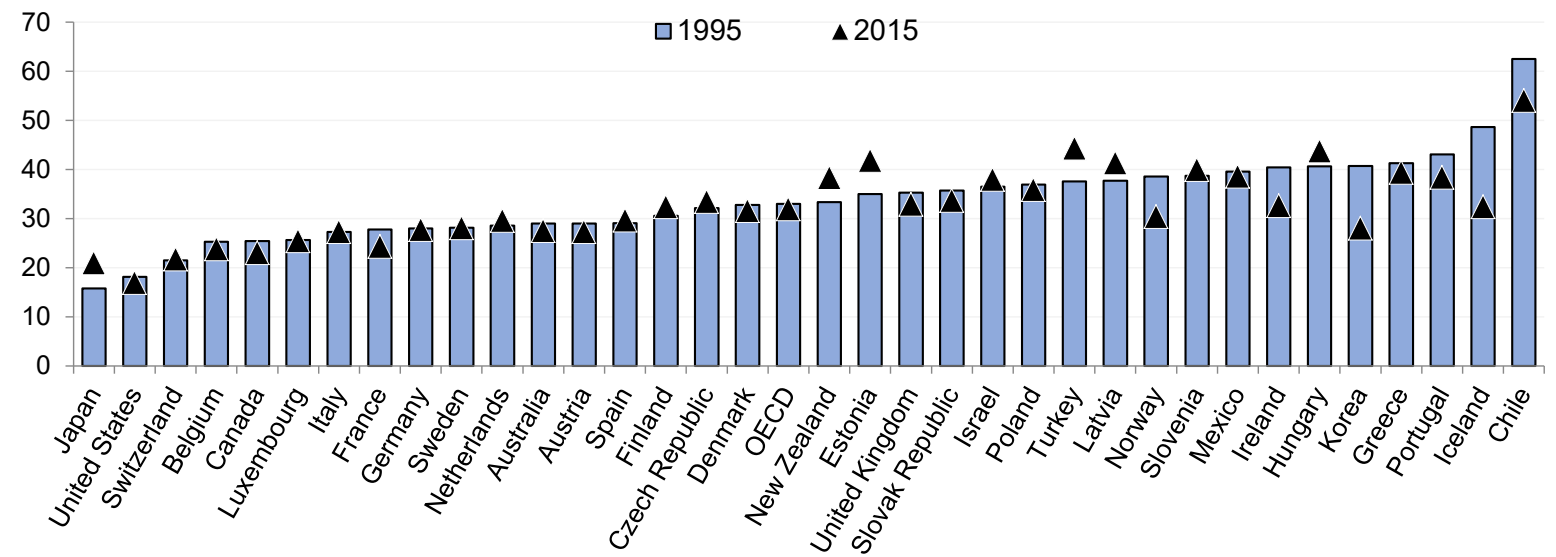

Panel E. Property taxes, as per cent of total tax revenues

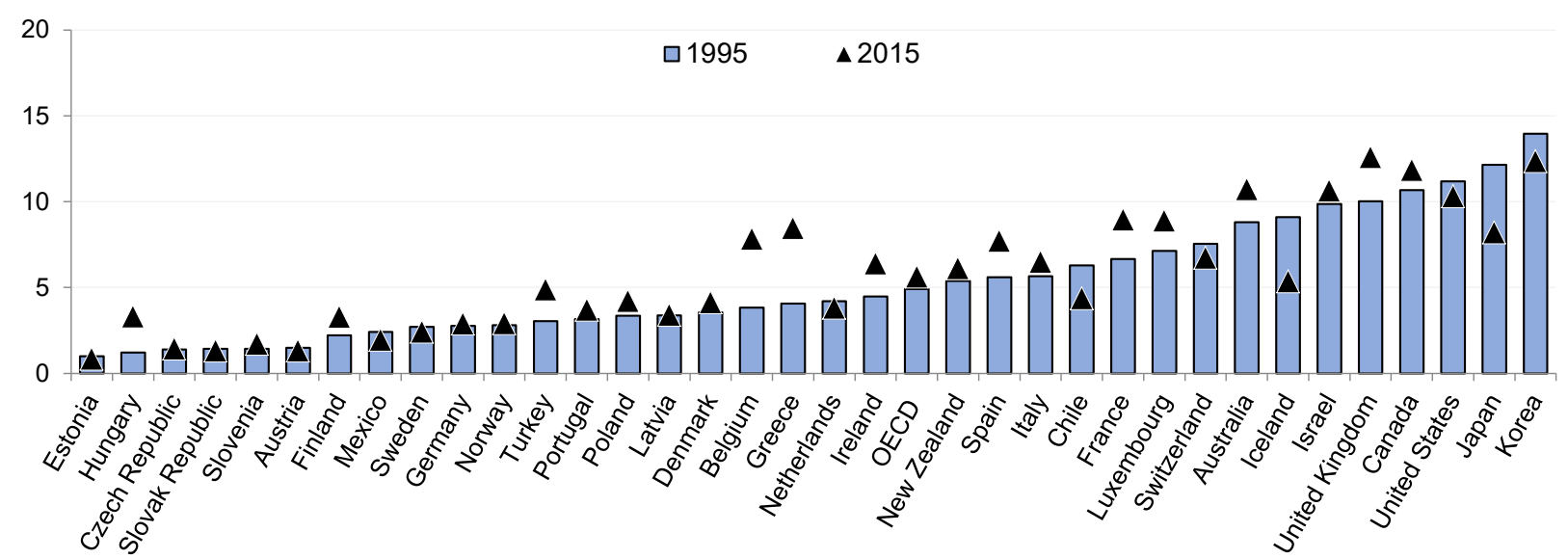

Source: OECD (2018), "Revenue Statistics: Comparative Tables" (Edition 2017)", OECD Tax Statistics (database), https://doi.org/10.1787/c5916521-en (accessed on 20 December 2017).

\section{The tax mix: Prescription versus practice}

This section examines, for each of five broad tax categories, the underpinning for anticipations of each tax's distortionary potential, followed by a brief summary of the evidence supporting its ranking in terms of inclusive growth. For each tax, the section then turns to frequently encountered tax policy challenges as gleaned from close to two dozen OECD Economic Surveys since 2008 which gave special attention to tax policy issues (Annex Table 1). These chapters or sections provide useful insights into opportunities for and constraints on governments seeking to shape tax policies for inclusive growth. 


\subsection{Property taxes}

\subsubsection{Guidance from cross-country evidence}

Property taxes include levies on immovable property (land and buildings), on inheritances and gifts, on net wealth, and on financial and capital transactions. As a general rule, taxes on immovable property create minimal distortions because they do not incite behavioural responses to the extent that other levies do, and they are difficult to evade (Johansson et al. (2008) and Arnold (2008)). ${ }^{1}$ Property taxes can also be seen as benefits taxes insofar as they are often imposed by sub-national governments to finance local public services, and can thus increase the accountability of local authorities.

Policymakers must also be concerned about the distributional consequences of taxes (Brys et al., 2017), which ultimately depends on the incidence of a tax. Given the high correlation between the distribution of income and the ownership of property in most countries, and absent offsetting provisions (e.g, caps on the level of the tax), property taxes tend to be progressive. At the same time, asset-rich but cash-poor households can be severely burdened by taxes on property. In addition, as an owner-occupied residence often is the principal asset of middleincome households, taxes on immovable property can be regressive vis-à-vis these taxpayers. However, such taxes can be targeted at high-income households (Bloch et al., 2016), or concessions provided to low-income or cash-constrained property owners. Horizontal equity concerns can also arise where, for instance, not all assessed property values (for tax purposes) reflect current market values.

Empirical work (Akgun et al., 2017) estimating the impact of various taxes on both growth and the income distribution points to positive impacts on growth of per capita income with a permanent but revenue-neutral shift of the tax mix toward immovable property. While revenueneutral shifts in taxes toward inheritance taxes are found to have significant inequality reducing effects, shifts toward immovable property have neutral distributional impacts. The evidence thus points to potential gains to inclusive growth from shifting taxes away from those that are more harmful to growth toward levies on immovable property and inheritances.

\subsubsection{Lessons from OECD Economic Surveys}

Although there are strong arguments in favour of revenue-neutral shifts in the tax mix toward taxes on immovable property in many OECD countries, there are relatively few instances where such a change has occurred. Figure 5 shows both total property taxes (top figure) and taxes on immovable property in 1995 and 2015. There was, on average, virtually no change in the share of taxes on immovable property during those two decades, rising by only about two tenths of a per cent of GDP. Some countries, however, witnessed fairly large increases, notably where (Belgium, Greece, Hungary, and Italy) such taxes were below the OECD average, and even more so in Hungary and Greece.

1. Taxation of real property via proxies for its value can, however, incite avoidance. Properties in Paris were at one time taxed on the basis of the number of street-side windows, which led to a surprising number of permanent closures of windows. Similarly, the narrowness of residences in the historical sections of Charleston, South Carolina reflects the architectural response to property taxes at the time when they were based on the frontage width of residences. 
Figure 5. Change in overall and immovable property taxes

Panel A. Property taxes as a per cent of GDP

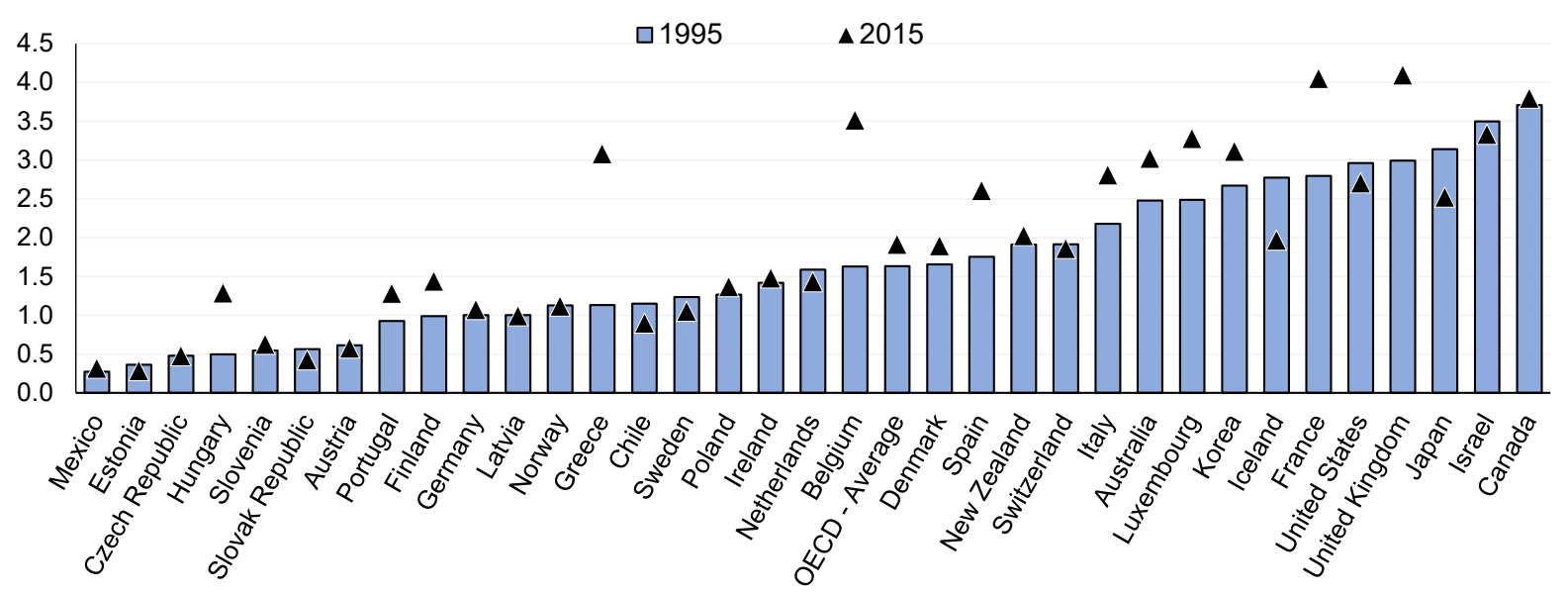

Panel B. Recurrent taxes on immovable property as a per cent of GDP

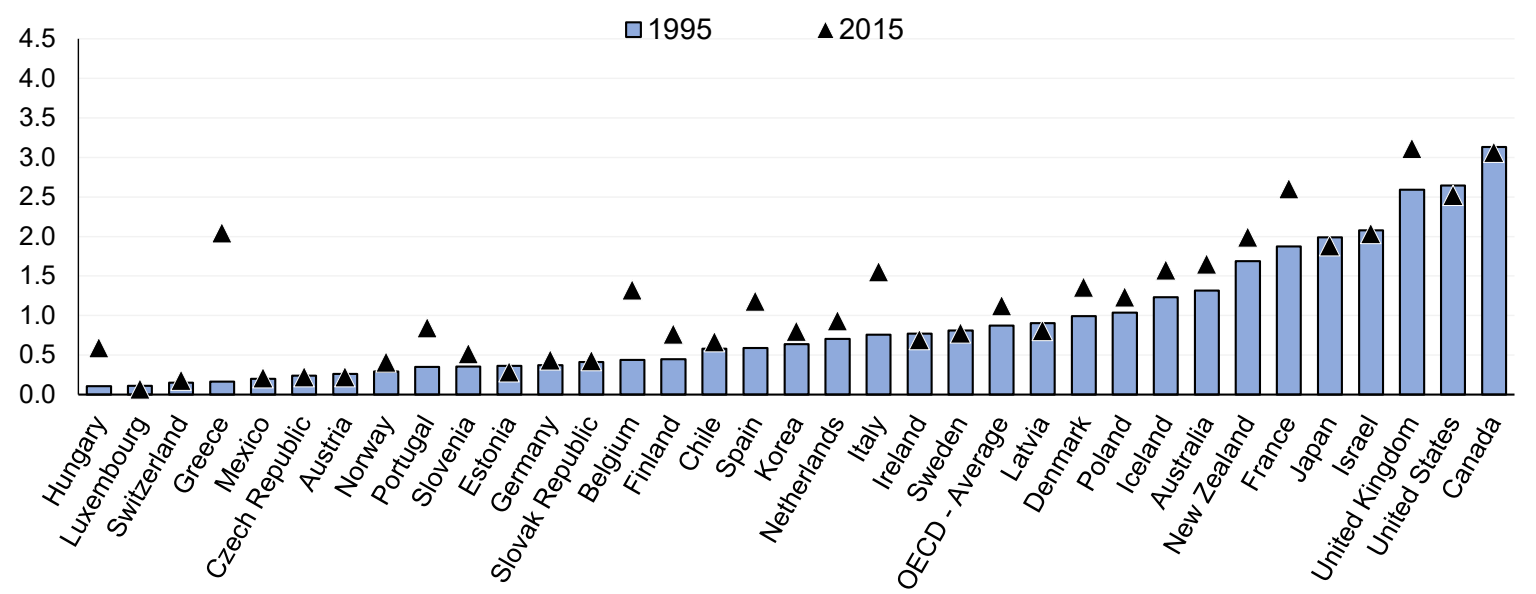

Source: OECD (2018), "Revenue Statistics: Comparative tables", OECD Tax Statistics (database), http://dx.doi.org/10.1787/data-00262-en (accessed on 11 February 2018).

Unsurprisingly, both for the superiority of immovable property taxes in minimising inefficiencies, and for the fact that such taxes are comparatively less important than others, governments have been frequently advised by the OECD to tilt the tax mix toward immovable property taxes. The authorities were urged in 22 countries to boost taxes on immovable property. A review of the OECD Economic Surveys containing detailed assessments of countries' systems points to some important obstacles to such a rebalancing.

\section{Outdated property values}

In many of the reviewed surveys, severely out-of-date assessed property values are highlighted as a serious obstacle to boosting revenues from property taxes. These include Estonia, Finland, France, Germany, Greece, Indonesia, Mexico, Portugal and Sweden. In turn, shifting taxes to immovable property could pose serious transitional challenges as vertical and horizontal inequities could arise, as well as spikes in tax liabilities for some households. Political 
constraints surrounding this could be significant. For instance, in Sweden, Sörensen (2010) reports that reforms in 2008 increased the bias in favour of investing in housing relative to other assets largely due to strong political opposition to property taxation.

Intergovernmental fiscal relations

Tax-setting authority varies across levels of government throughout the OECD, especially in those with a federal structure. As noted, with property taxation in many countries a principal source of sub-national government revenue, shifting the tax mix toward immovable property taxation can often encounter resistance at the sub-national level. Where sub-national governments receive transfers from the national treasury, increasing taxation of immovable property can be unattractive if such an effort results in reduced budgetary transfers or revenue sharing from the centre (e.g. Czech Republic, Hungary, Poland). In Finland, the central government imposes a cap on property tax rates but not on the tax on labour, over which municipal governments have rate-setting authority (Box 3). In Portugal, local governments have full control over transactions tax rates, but are constrained on immovable property taxes by a rate band set by the central government. As such, local authorities are less able or inclined to eliminate distortive transactions taxes.

\section{Box 3. Property taxation in Finland}

Unlike in many countries, the largest source of tax revenue for funding municipal government expenditure is the tax on personal income. Recognizing the greater mobility of capital than labour, Finland, as do the other Nordic countries, uses a dual-income tax system whereby income from capital (interest, dividends, capital gains) is taxed at a uniform and lower rate than earned income. Although the personal income tax base is determined nationally, municipalities determine the tax rates on labour income. By contrast, local governments have less control over the tax rates on immovable property; they are constrained to set rates within minimum-maximum bands set by the central government. The mere existence of a cap on the rate at which immovable property can be taxed constrains the options available to municipalities to improve local tax efficiency. As underscored in OECD Economic Surveys, this system results in a counterproductive outcome of rising marginal and average tax rates on labour and a reluctance by municipalities to shift revenue toward immovable property. Additionally, taxable values, which are updated by the Ministry of Finance, have tended to lag market values.

Recent years have witnessed a shift away from favouring home-ownership and toward increasing overall taxation on immovable property. The minimum-maximum bands within which municipal governments can set their property tax rates have been widened. Property assessments have been revised to better reflect market values, and cadastral values are expected to be completely updated by 2020. Finally, preferential taxation in favour of owner-occupied housing is being gradually reduced.

\section{Legal obstacles}

In some countries, legal obstacles prevent the fiscal authorities from raising property tax revenues. In Hungary, a national recurrent tax on immovable property was annulled by the Constitutional Court in 2010, and authorities debated in 2011 to allow local governments to raise as much as $3 \%$ of GDP from such taxes, without, however, implementing such a change.

\section{Difficulties in taxing imputed rents}

An alternative to the direct taxation of property is to tax the income it generates, whether such rents are explicit or implicit (imputed rents). Income from rental properties are in general taxed via personal or business income tax systems. In the large majority of OECD countries, however, owner-occupied housing receives preferential treatment over other assets, including: (i) non-taxation of implicit rental income, while (ii) nonetheless allowing mortgage interest costs to 
be deducted from the personal income tax base, and (iii) exempting from capital gains taxation on the sale of owner-occupied housing. ${ }^{2}$ Among the Economic Surveys reviewed, only in Belgium were imputed rents subject to income tax, but the policy was reversed. Canada and France are two of the few countries where mortgage interest payments are not deductible from personal income in the calculation of tax liability. ${ }^{3}$ Mortgage interest deductions are phased out in the United Kingdom, and Finland and Ireland are eliminating them gradually over time. In all countries, governments were advised to either take steps to tax imputed rent, or to eliminate the deductibility of mortgage interest.

\section{Setting the stage for a shift to immovable property taxes}

The above discussion suggests some potentially critical and necessary preconditions for increasing the share of taxes on immovable property. First, property taxes tend to be unpopular, and the political economy challenges surrounding any increase in their share are obviously delicate. ${ }^{4}$ Where property taxes are an important source of local government revenue, policy recommendations to national authorities to effect a revenue-neutral shift toward property taxes ought to be accompanied by compensatory schemes that are feasible within the country's intergovernmental fiscal framework. Second, in most countries, tilting the tax mix toward immovable property taxes would require a demanding holistic approach whereby the overall tax treatment of real estate is considered at the same time (i.e. including the different tax provisions that favour immovable property, such as the non-taxation of imputed rental income, while nonetheless allowing the deductibility of mortgage interest costs). Third, where property assessments are far from market values, redressing the undervaluation of the tax base would seem to be a necessary precondition to initiating a shift. Finally, having a solid understanding of the progressivity or regressivity of the tax in advance is essential for conceiving ex ante offsets for low-income taxpayers.

\subsection{Consumption taxes}

\subsubsection{Guidance from cross-country evidence}

Consumption taxation has some distinct advantages. Theoretically, a lifetime tax on consumption does not distort the choice between consumption today and future consumption, and thus does not distort saving decisions, although it will distort the work/leisure choice (Box 4). ${ }^{5}$ Given the crucial role of domestic saving in funding investment, which is in turn critical for productivity growth, a consumption tax is less unfavourable to per capita income growth than a tax on income. The growth advantage of consumption taxes is confirmed empirically in the work

2. In the United States, local property taxes are also deductible from income in the calculation of Federal income tax owed. This was recently reduced in the Tax Cuts and Jobs Bill enacted in late 2017, which capped the deduction for state and local income taxes at USD 10 000, thereby reducing the Federal subsidy to local governments heavily dependent on taxes on immovable property.

3. In France, the disallowance of the deductibility of mortgage interest applies only to mortgages contracted after December 31, 2010.

4. The 1978 Proposition 13 in the US state of California is a prime example of the challenge of increasing property tax. The proposition, endorsed by a sizeable majority of voters and upheld by the US Supreme Court, established a maximum amount of any ad valorem tax on real property.

5. This neutrality depends on the sensitivity of private savings to the after-tax rate of return on saving, about which there is some empirical uncertainty (Hall, 1988 and Summers, 1982). 
of Johansson et al. (2008), Arnold (2008), Arnold et al. (2011) and Akgun et al. (2017), who provide empirical evidence that a revenue-neutral shift in the tax mix toward consumption has a much less adverse impact on GDP growth per capita than taxing income, corporate or personal.

\section{Box 4. Key considerations in tax policy choices}

In formulating and assessing tax policy, it is important to differentiate the economic costs of each source of government revenue. Taxation of either consumption or labour discourages labour supply relative to what it would otherwise be because the after-tax return to the worker is less than the cost to the employer. This tax wedge exists whether wages are taxed directly or indirectly via an indirect tax on consumption of goods and services (which lowers the after-tax real wage). The tax wedge is greater the greater is the total marginal tax rate on labour income. Social insurance contributions are different from a tax per se since they in principle pay for social benefits, notably for lower income households insofar as benefits tend to be more proportional to contributions below certain income threshold levels. To the extent that the linkage between such contributions and associated benefits is weak or non-existent, however, the contributions will have the same effect as a tax on wages, and this is true whether the contributions are collected from the worker or the employer.

A tax on capital income drives a wedge between the before- and after-tax return to capital. It discourages saving by discriminating against future relative to current consumption. This tends to reduce investment and thus in turn productivity growth.

It is worth emphasizing that a tax on labour income alone can, in the long run, be equivalent to a tax on only consumption. With a constant (over a lifetime) and proportional tax rate on either labour income or consumption, both are neutral toward consumption today or consumption tomorrow.

Beyond these major distortions, there are of course many ways in which the actual structure and design of either tax can and will impact economic behaviour. Thus, for instance, differential taxation of labour income across professions or sectors of the economy will impact current and future workers' choices. Uneven tax rates on returns on different capital assets will result in savings and investment patterns that differ from more neutral taxation. The ultimate impact of a tax hinges on its incidence. Indeed, the final burden of a tax need not be, nor is it generally, borne by the persons or entities from whom the statutory tax is collected. Depending on elasticities of demand and supply, a tax may be shifted forward or backward to be borne ultimately by others.

The incidence of taxation is critical to assessments of the distributional impact of taxes. However, evidence on incidence is not always clear-cut, as illustrated by the VAT. Given the higher share of consumption in low-income households than in high-income ones, proportional taxation of consumption is thought to be regressive. Empirical inquiry into the incidence of the VAT, however, demonstrates that the VAT is not unambiguously and everywhere regressive. Evidence of VAT's regressivity tends to derive from analyses of VAT burdens measured as a share of income in a single year (O'Donoghue et al., 2004; Leahy, Lyons and Toll, 2011; and Ruiz and Trannoy, 2008). But this approach fails to account for the fact that income not consumed in one period (i.e. saved income) will be consumed in a subsequent period. A lifetime approach is therefore needed to appropriately assess the distributional impact of taxes on consumption. Recent empirical analysis by Thomas (forthcoming) based on a micro-data set of households finds, by taking the specific design of the VAT across countries into account, that, overall, lifetime VAT is generally proportional or slightly progressive using expenditure as a proxy for lifetime income. 
Consumption is taxed indirectly via a VAT or a retail sales tax, as well as through excise taxes or import duties. ${ }^{6}$ As noted, the role of VAT has risen, while that of specific taxes has diminished substantially in most OECD countries during the past several decades. Virtually all OECD countries rely on a VAT or a Goods and Services Tax (GST), while the United States relies mostly on state and local retail sales taxes.

There are strong arguments in favour of a consumption tax being imposed on all goods and services and at a unique rate. Applying a unique tax rate to a broad base simplifies administration and compliance, and the combination helps ensure horizontal equity. In practice, however, most countries typically introduce lower (including zero) rates (Annex Table 3) and/or exemptions for selected goods and services deemed to be necessities. It is widely acknowledged, however, that this approach complicates both administration and compliance. Worse, the approach tends to favour better-off consumers.

The overall reduction of VAT revenue is due mostly to policy choices, be they aimed at reducing perceived regressivity or at promoting social objectives or economic activity in one or another sector or industry. Revenue can also be lost due to fraud and weak compliance. A measure of the reduction of VAT revenue is the so-called VAT revenue ratio (VRR). The VRR provides a comparative measure of the extent to which exemptions and preferential lower tax rates, as well as poor compliance and fraud, reduce revenue relative to its potential level. The higher the ratio, the greater are the combined impacts of effective compliance and a broad base taxed relatively uniformly (i.e. where there are few goods and services subject to a lower statutory rate). Conversely, a low ratio reflects a combination of reduced rates and weak compliance. Ranging from $32 \%$ in Mexico to close to $100 \%$ in New Zealand during 2005-09, the unweighted average ratio remained essentially unchanged in the subsequent five years (Figure 6 and Annex Table 3).VAT revenue can also fall, relative to GDP, when consumption decreases as a driver of economic activity, as has been the case for instance in Ireland following the crisis in 2008.

Shifting the tax mix toward greater reliance on consumption taxation could be favourable to inclusive growth. There are two aspects to this empirical question. First, could the positive growth impact of a revenue-neutral change in the mix away from more distortive taxes (such as on income) to consumption taxation be sufficiently strong to offset the increased tax burden on the lower-income members of society? Estimates reported by Akgun et al. (2017) suggest that such a tax mix change would have no significant effects on disposable income inequality if it involved increases in the statutory VAT rate. But it could increase disposable income inequality if it involves hikes in fuel taxes. Even for the VAT, such a shift could nonetheless have an adverse distributional impact at the consumption stage. This risk does not appear material for increases in the statutory rate of VAT, as a number of studies have found that VAT payments in total consumption tend to be either proportional or slightly progressive (Decoster et al., 2010; Pestel and Sommer, 2013; and OECD, 2010c). Second, if the growth impact of a change in the mix is sizeable but regressive, governments have compensation options, including cuts in even more regressive taxes (e.g. cutting high marginal income tax rates faced by low-income earners) due to benefit withdrawals, or increasing well-targeted social transfers.

6. Consumption taxation can also be effected directly through the personal income tax system. Most countries' personal income tax systems are hybrid schemes that include a mix of income and consumption taxation via favourable tax treatment of net additions to savings, such as deferred taxation of contributions (and interest earned on the accumulated funds) to retirement accounts. 
Figure 6. VAT revenue ratios and standard VAT rates Panel A: VAT revenue ratios $(\mathrm{VRR})^{1}$

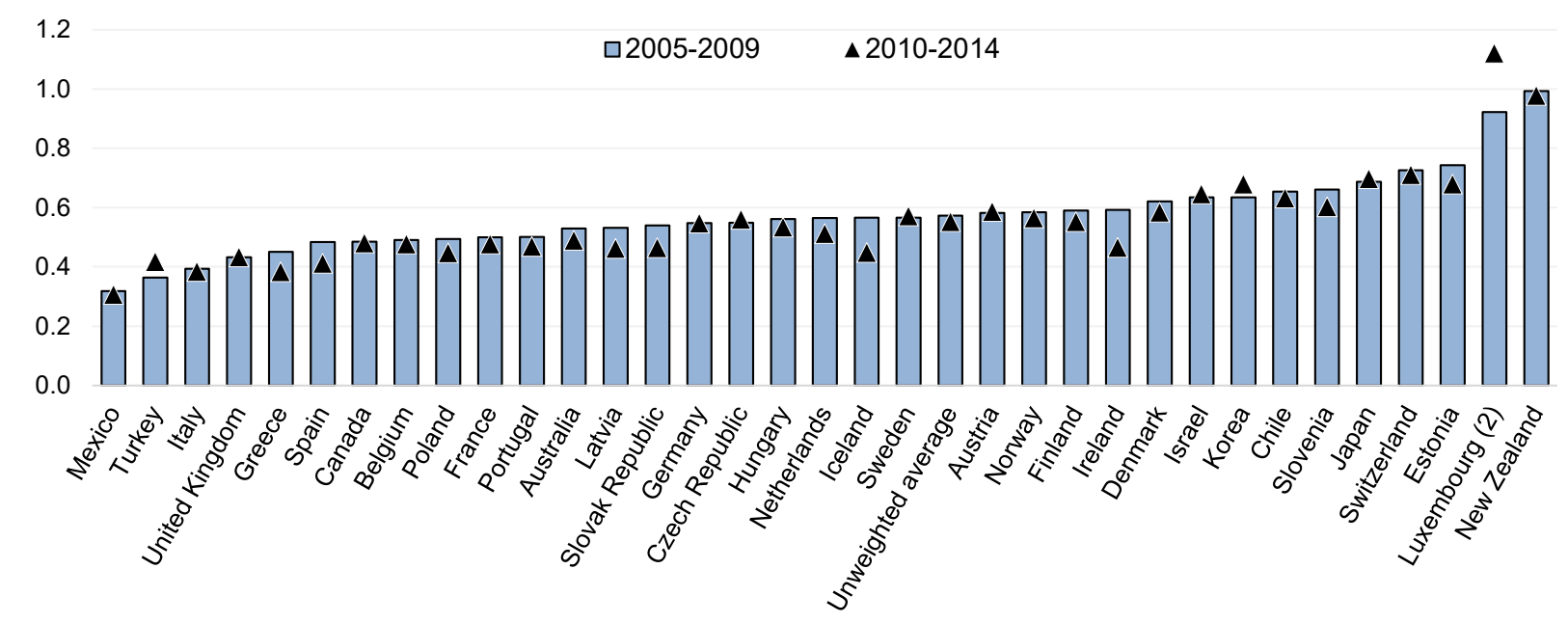

Panel B: Standard VAT rate in 2014

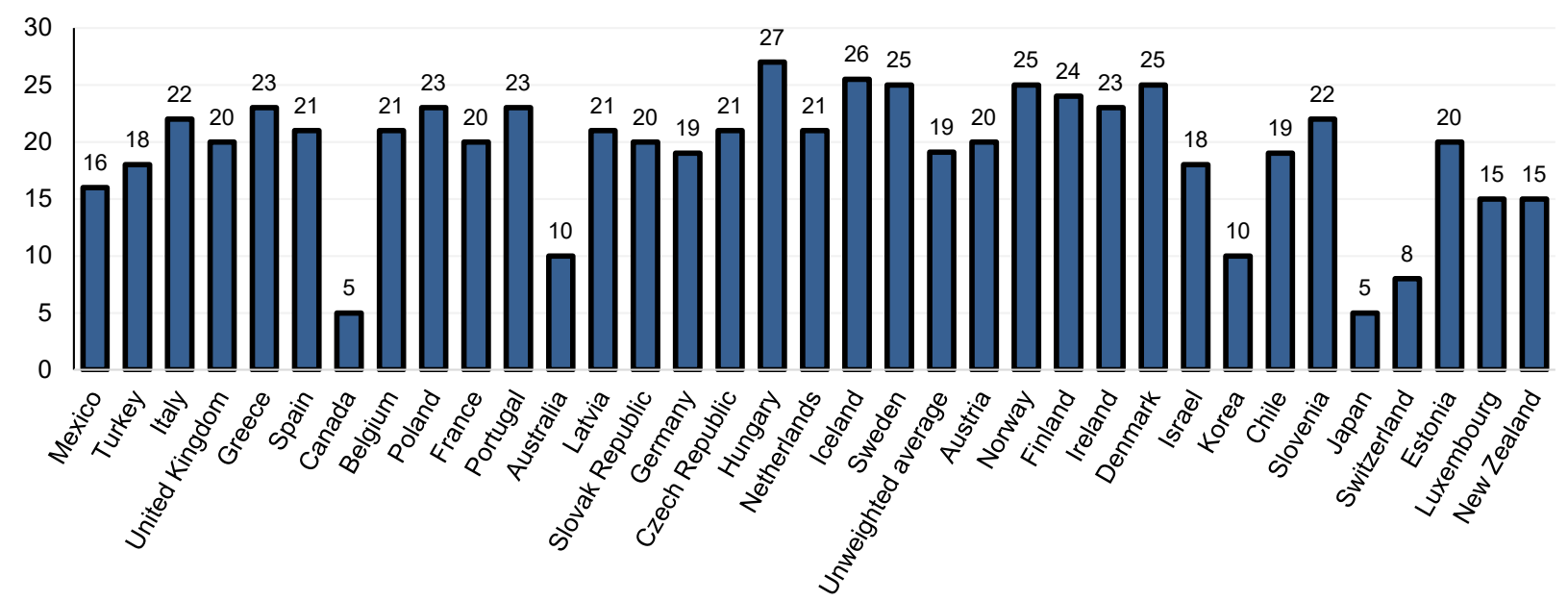

1. The VRR is defined as the ratio of actual VAT revenue to revenue that could be potentially collected by applying a single rate to aggregate consumption.

2. Luxembourg's high VRR is related to the liberalisation of financial services and to the boom in e-commerce, and to pre-2015 EU VAT provisions. Since January 1, 2015, EU VAT rules have changed in a manner that should lower its VRR.

Source: OECD (2016a), Consumption Tax Trends 2016: VAT/GST and Excise Rates, Trends and Policy Issues, OECD Publishing, Paris, http://dx.doi.org/10.1787/ctt-2016-en.

\subsubsection{Lessons from OECD Economic Surveys}

From the earlier discussion, it is evident that OECD countries are not averse to relying on consumption taxes. Consumption taxes, as measured by indirect taxes, account on average for a third of total tax revenue, ranging from as low as $17 \%$ of general government taxes in the United States to as high as $54 \%$ in Chile (Annex Table 1). Among a sample of countries reviewed for this paper, a modest increase in the share of consumption taxes in total tax revenue is observed in the Czech Republic, Estonia, Israel and Sweden over the period 1995-2015, with relative stability or declines in the other countries (Figure 7). In view of the strong evidence of the less distortive impact of consumption compared to other taxes, it is useful to glean from the detailed analyses in survey chapters the extent to which governments were urged to pursue tax mix changes in favour of consumption, and to highlight obstacles encountered by governments. 
Figure 7. General consumption taxes in total revenue

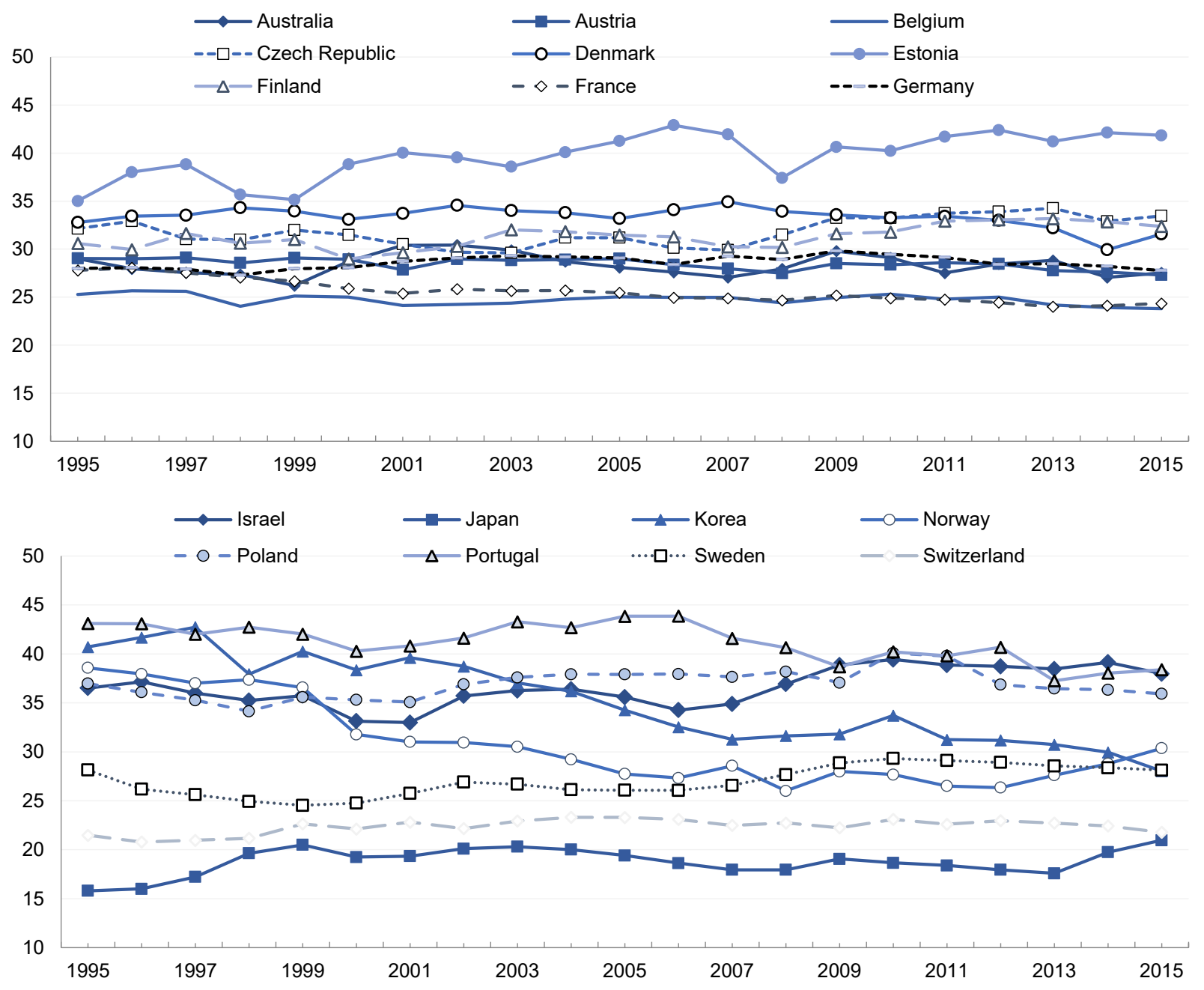

Source: OECD (2018), Revenue Statistics: Comparative Tables, OECD Tax Statistics (database), http://dx.doi.org/10.1787/data00262-en (accessed on 20 December 2017).

It is readily evident from OECD Economic Surveys that governments are routinely urged to reform policies and improve collection of VAT. The VAT or GST received special focus in the analysis of over half of the countries whose tax systems were reviewed during 2008-17, and all contained recommendations that the VAT base be expanded and/or that reduced rates be eliminated or raised. By and large, however, reforms of indirect consumption taxation along the lines of base broadening and single rating have been difficult to achieve. Standard VAT rates are already relatively high in most countries (Annex Table 3 ) and often close to the turning point above which they might not generate additional revenue (Akgun et al., 2017). Against this background, any shift in the tax mix toward indirect taxation will generally require a broadening of the base subject to the standard rate. Many countries have made marginal adjustments such as increasing reduced rates or reducing their scope. Since 2009, these include Austria, Belgium, the Czech Republic, Estonia, France, Luxembourg, the Netherlands and Norway. Several reasons or circumstances underpin the hesitancy of governments to undertake more comprehensive shifts toward indirect taxation, notably VAT. 
Governments consider exemptions and reduced rates as progressive

In most OECD Economic Surveys, the authorities support reduced VAT rates and sectoral exemptions from VAT because they perceive the VAT to be regressive. However, these tax preferences also benefit untargeted groups, notably the better-off. For instance, in Mexico, higher income households capture the largest part of the benefits in absolute terms (OECD Economic Survey of Mexico, 2011). ${ }^{7}$ In France, although reduced rates for essentials and services are usually justified on equity grounds, empirical evidence suggests this is misplaced. The 2013 OECD Economic Survey of France notes two studies that illustrate the ineffectiveness of these policies. Bozio et al. (2012) find that, in France, rich households benefit much more from reduced rates than do the poor. Unsurprisingly perhaps, Ruiz and Trannoy (2008) conclude that reduced VAT rates for restaurant meals and yachts are of greater benefit to better-off households than to lower-income persons.

To be sure, such ostensible "benefits" are more easily administered than means-tested cash payments. But they also add substantially to the private sector's compliance burdens compared to a broad, single-rate scheme. Moreover, the budgetary costs of such tax expenditures are less measurable and controllable than explicit outlays on low-income support programmes. In the absence of the political will to acknowledge the lifetime proportionality of indirect taxes, politicians are likely to remain opposed to further increasing the share of consumption taxation.

Political economy arguments implicitly loom large

Tax reforms unavoidably entail a redistribution of the tax burden; there are always winners and losers. Beyond the distributional goals that nominally underpin most countries' preferential VAT provisions, there also exist many industry or sectoral carve-outs founded on a range of ostensible economic arguments. For instance, reduced VAT rates on accommodation and restaurants were introduced or considered in Ireland and Switzerland to boost employment in the labour-intensive tourism industry. A similar policy was pursued in France for restaurants as a prospective stimulus measure following the financial crisis in the late 2000s. In addition to exemptions based on distributional concerns such as food, basic health care, and education, exemptions are also prevalent for culture, legal aid, passenger transport, public cemeteries, waste, water supply, precious metals and agriculture (OECD, 2016). Given the economic rents accruing to favoured sectors, powerful political pressures are typically mobilised to preserve the status quo.

Weak tax administration can be an obstacle

Although the VAT is largely self-administered, minimising revenue leakages hinges on a well-developed tax administration to ensure strong enforcement and compliance. In some countries, such as Turkey, Mexico and Indonesia, weaknesses in tax administration are a noted obstacle to boosting revenue from indirect taxation, in turn limiting the countries' ability to reduce more harmful taxes. The prevalence of exemptions and reduced rates further complicates VAT administration and compliance. Most OECD countries apply exemption thresholds below which small businesses are not required to charge and collect the VAT. While there are no definitive

7. In 2009, the government proposed a reform to introduce a $2 \%$ rate on all sales including food and medicines, while increasing benefits for low-income households. Parliament, however, rejected the proposal and opted instead for an increase in the standard rate. 
justifications for the need, or the level of, such a threshold, the main argument is to avoid overburdening small firms for which compliance costs would be disproportionate to the revenue owed. Since much of compliance costs can be attributed to reduced rates and exemptions in the first place, an easier solution would seem to be to simply broaden the base and apply a single rate. Moreover, a low threshold can be a disincentive to expand the firm, while a high threshold can be costly in potential revenue losses.

Intergovernmental relations

In some countries, consumption taxes are also important for sub-national governments, posing special challenges to increasing consumption tax revenue at the national level. In the United States, retail sales taxes are fully left to states and local governments. Introduction of a national indirect tax on goods and services (whether a VAT or retail sales tax), as recommended in OECD Economic Surveys, would likely create significant political turmoil, especially where the retail sales tax is already relatively high. In addition, given the wide variation in tax bases across US states, a national tax would be a significant administrative and political challenge to get adopted and implemented. In Brazil, states have full autonomy to set VAT rates within bands set by the central government, and have partial autonomy to determine the base. Intra-state rates can be set within a range, with basic goods typically exempt. Because of the complexity and fragmentation of the tax code (OECD Economic Survey of Brazil, 2009), and given the autonomy accorded to states, the latter have frequently used the VAT as a form of industrial policy to offer competitive rates to attract investment. This predatory tax competition posed serious challenges to the Brazilian authorities in tilting the tax mix toward VAT.

Setting the stage for boosting the share of consumption taxation

The increasingly convincing empirical evidence (OECD/KOPF, 2014) that the VAT is not regressive when measured as a percentage of expenditure offers governments firmer grounds on which to undertake a shift in the tax mix toward consumption taxes. Of course, even if indirect taxation of general consumption is found not to be substantially regressive, the burden on poor households can nevertheless be sufficient to warrant compensation. One option is a refundable and targeted tax credit. Many countries have introduced negative income taxes, normally attached to work requirements (e.g. the Working Income Tax Benefit in Canada and the Earned Income Tax Credit in the United States). Other options include means-tested in-kind benefits such as food stamps as in the United States, or increases in targeted cash benefits.

\subsection{Environmental taxes}

\subsubsection{Guidance from cross-country evidence}

The past several decades have witnessed increased policy action to address climate change and pollution more generally. This has encompassed market-based mechanisms, including tax instruments and tradable emission schemes, to discourage economic behaviour that has harmful environmental impacts (OECD, 2016b; and OECD 2018). Although command and control regulatory tools such as mandated rising average vehicular mileage targets and reductions in power producers' allowable greenhouse gas emissions continue to be used, a preference for more market-based mechanisms has gradually reached general consensus among policymakers. Such measures include a range of options, including excise taxes levied on carbon-based polluting products such as transport and home heating fuels, carbon taxes, and tradeable emission rights. In principle, such levies are not intended to generate revenue per se, but are instead aimed at internalising the environmental costs due to the use of the product in 
question. Notwithstanding, the revenue potential of environmental taxes and other market-based instruments can be substantial. Marron and Morris (2016) report that British Columbia in Canada collects roughly USD 700 million from its carbon levy, while McKibbin et al. (2015) estimate that the United States could raise around USD 100 billion or more annually from a broad-based carbon tax. Notwithstanding the revenue potential, environmentally-related revenues declined as a share of GDP in most OECD countries during 1995-2014 (Figure 8).

Figure 8. Revenues from environmentally-related taxes

Per cent of GDP

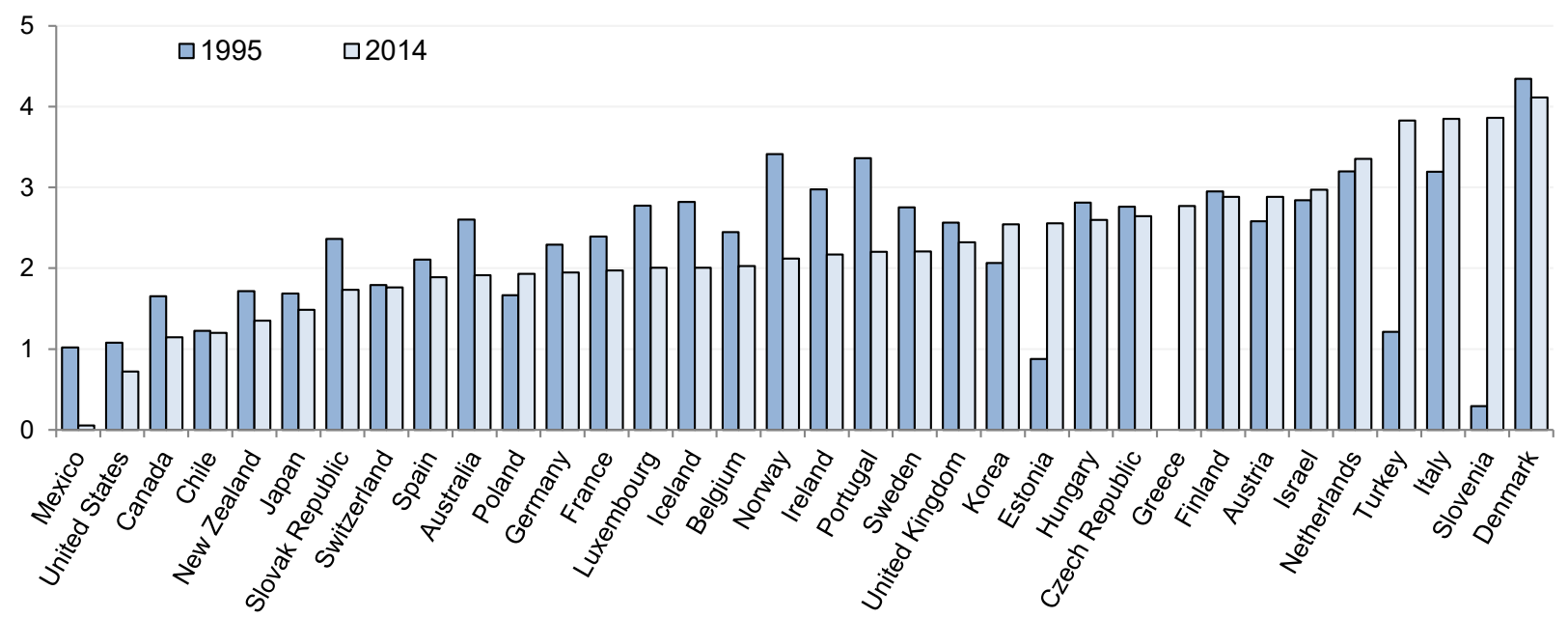

Note: Latest data for Poland refer to 2013. Data not available for Greece for 1995.

Source: OECD (2018), "Environmental policy: Environmental policy instruments (Edition 2017)", OECD Environment Statistics (database), http://dx.doi.org/10.1787/data-00696-en (accessed on 9 April 2018).

While a key objective of environmentally-related taxes is to reduce harm to the eco-system and thereby improve welfare generally, key concerns often expressed by policy makers are the potentially adverse impacts of such levies on growth and on the disposable incomes of poor households. In judging the growth impact of environmental taxes, an important consideration is the use to which the revenues generated by the levies are put. Flues and van Dender (2017) show that any adverse impact on vulnerable population groups from taxes and higher prices could be better addressed by targeted benefit schemes. As stressed by Johansson et al. (2008) and Brys et al. (2016), whether growth is favoured by increased environmental taxes used to reduce more distortive taxes (e.g. corporate taxes and taxes on labour) depends on the level of environmental taxes prior to any increase, the supply and demand elasticities of the taxed goods and services, and which other taxes are reduced. In their cross-country empirical work, Akgun et al., (2017) find that environmental taxes have no impact on long-term output, which is consistent with findings by Albrizio et al. (2014) that environmental regulation more generally has a neutral impact on productivity.

Although environmentally-related taxes are generally perceived to be regressive, there is relatively little empirical evidence to confirm this perception. Recent research (Flues and Thomas, 2015) underscores that the distributional impact varies by energy product and across countries. Taxes on heating fuel and electricity tend to be regressive. By contrast, as a percentage of current spending, taxes on transport fuels tend to be progressive in the lower half of the income distribution, reflecting the lower rate of vehicle ownership among poor households. The burden tends to decline in the upper income brackets, most likely because of the greater reliance on alternative modes of transportation, including both public and private. 


\subsubsection{Lessons from OECD Economic Surveys}

Due in large part to the empirical evidence noted above, governments have been urged to increase the weight of environmental taxation to finance cuts in harmful distortions associated with some other taxes. Recommendations to increase or broaden excise taxes to cover more carbon-based products, and to differentiate them based on the $\mathrm{CO}_{2}$ emission content, figured in numerous OECD Economic Surveys during the past decade: Austria, Belgium, Canada, Columbia, Estonia, Israel, Korea, Mexico and Poland. In some countries, simple indexing of excises to inflation would contribute to more effective environmental taxation. Canada and the Czech Republic were urged to consider emission taxes to combat GHG emissions. ${ }^{8}$ On the other hand, environment-related taxes in some countries (e.g. Denmark) have risen beyond levels justified by the damaging effects of the use of the good, and authorities were urged to use caution in raising them further.

\subsection{Personal income taxes and social security contributions}

\subsubsection{Guidance from cross-country evidence}

Direct taxation of individuals' income can be harmful to economic growth. As noted in Box 4, income taxation creates two potentially powerful distortions: i) it discourages labour supply by reducing the relative price of leisure; and ii) it reduces saving by lowering the after-tax rate of return to capital.

There is ample empirical evidence on the scope and size of distortions caused by personal income taxation (including social security contributions). ${ }^{9}$ The empirical work undertaken at the OECD concludes that personal income taxes are the second most damaging tax to growth of per capita income (Johansson et al., 2008 and Arnold, 2008). The harm occurs through several channels: high marginal tax rates reduce labour utilisation, and they lower productivity by adversely affecting entrepreneurship. Although the extensive literature on the optimal marginal tax rate is inconclusive, it is generally accepted that high marginal tax rates are especially harmful at the lower and upper portions of the distribution of earnings. At the low end, high marginal tax rates, including those resulting from the gradual withdrawal of targeted, meanstested benefits, create strong incentives to reduce work effort at both the intensive and extensive margins. At the upper end of the income distribution, high marginal tax rates can reduce work effort at the intensive margin. They also have other pernicious effects such as reduced risktaking, lower saving, induce out-migration to lower-taxed countries and increased tax avoidance, among other things. Thus, excessive progressivity at upper-income levels also poses risks for growth.

8. Although not benefiting from a thematic chapter on taxation per se, the 2010 Economic Survey of the United States stressed the large revenue and environmental potential of a carbon tax in the United States.

9. See OECD (2010c) and references therein. 
If reductions in marginal income tax rates might boost per capita income growth, they also reduce progressivity and, at first glance, increase inequality. The recent cross-country research undertaken at the OECD on taxation and inequality offers empirical evidence on the impact of shifts away from income taxation toward less distortive taxes (Akgun et al., 2017). The empirical methodology takes into account the joint impacts of (i) the effects on inequality due to reduced marginal and average income tax rates on the one hand, and (ii) the boost to incomes across the income distribution attributable to the revenue-neutral shift in taxes on the other hand. Key results emerging from the research are that revenue-neutral changes to tax wedges below and above, rather than near, average incomes most influence long-term growth:

- Reducing the tax wedge at low income levels, while raising other taxes to keep overall revenue constant, raises long-term output and reduces inequality.

- Increasing the tax wedge on above-average incomes, also while keeping overall government revenue constant, reduces long-term growth and inequality. Despite narrowing income differentials, higher progressivity still reduces the absolute level of income at the bottom. Indeed, simulations based on the empirical estimates indicate that households earning less than the average lose more, in absolute terms, as a result of a generally less efficient economy when progressivity is greater above average, than they gain by getting closer to the upper part of the distribution.

In light of this evidence, a worthy query is the extent to which countries' personal income tax and transfer policies during the past decade or so have moderated the parameters of their personal income tax and transfer systems to reduce their distortive potential. Figure 9 shows the personal income tax and overall tax wedge (which also takes into account both social security contributions and transfers) progression on average in the OECD, at different income levels and for different family types. ${ }^{10}$ Looking at Panel A, progressivity is highest at the bottom of the income scale and declines with income for all family types. Tax wedge progressivity is generally lower than PIT progressivity since the tax wedge includes social security contributions, which are typically levied at a flat rate. Moreover, tax wedge progression is lower than the average PIT progression for families without children because the latter tend not to receive benefits, which also tend to be targeted at low income levels. This explains in part the higher rate of tax wedge progressivity than of personal income tax at low levels. For families with children, two factors raise the progressivity of the tax wedge: (i) benefits are often fixed amounts, and (ii) they are phased out as income rises. Panel B of Figure 9 highlights the fact that personal income tax systems had become more progressive by 2012 at lower income levels while they had become slightly less progressive at upper income levels. The increased progressivity at low-income levels reflects initiatives in many countries to encourage employment of low-income workers and to tie benefits to work (such as via earned-income tax credits) (Causa and Hermansen, 2018).

10. Progression is calculated as the change in the average personal income tax rate or in the average tax wedge, per percentage point increase in income, measured as a multiple of the average wage. 
Figure 9. Average PIT rate and tax wedge progression across the OECD

for 6 household types, by income level

Panel A. 2012

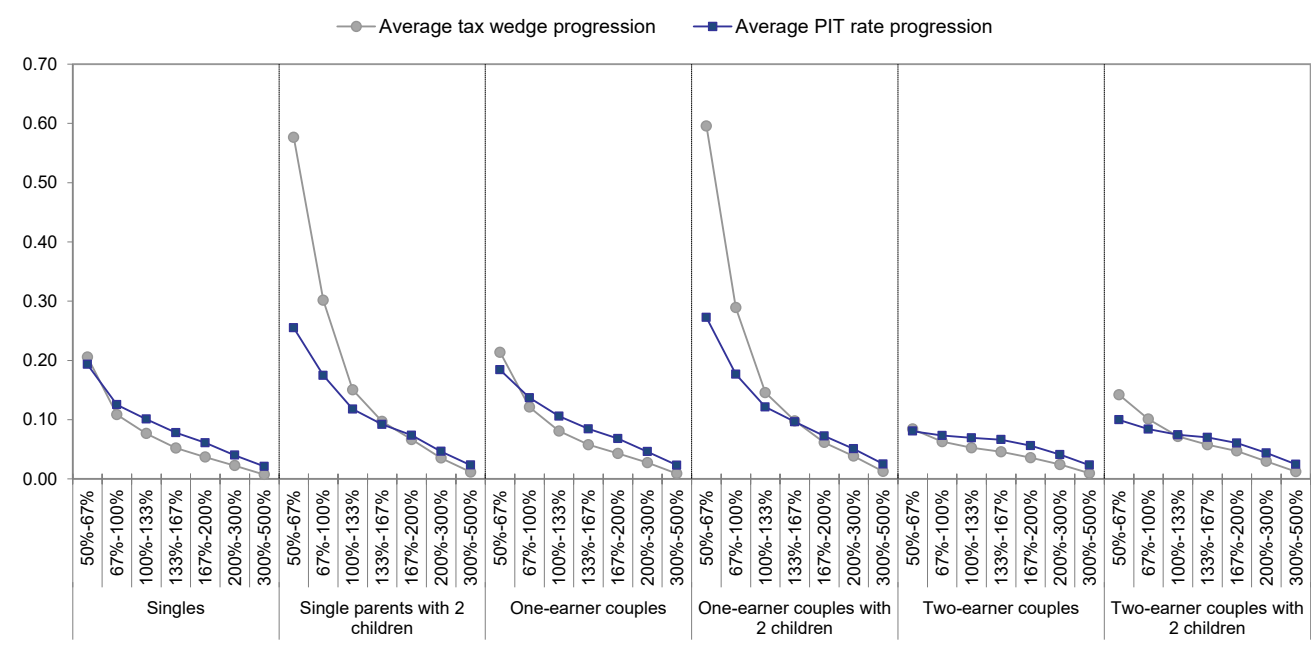

Panel B. Change during 2000-12

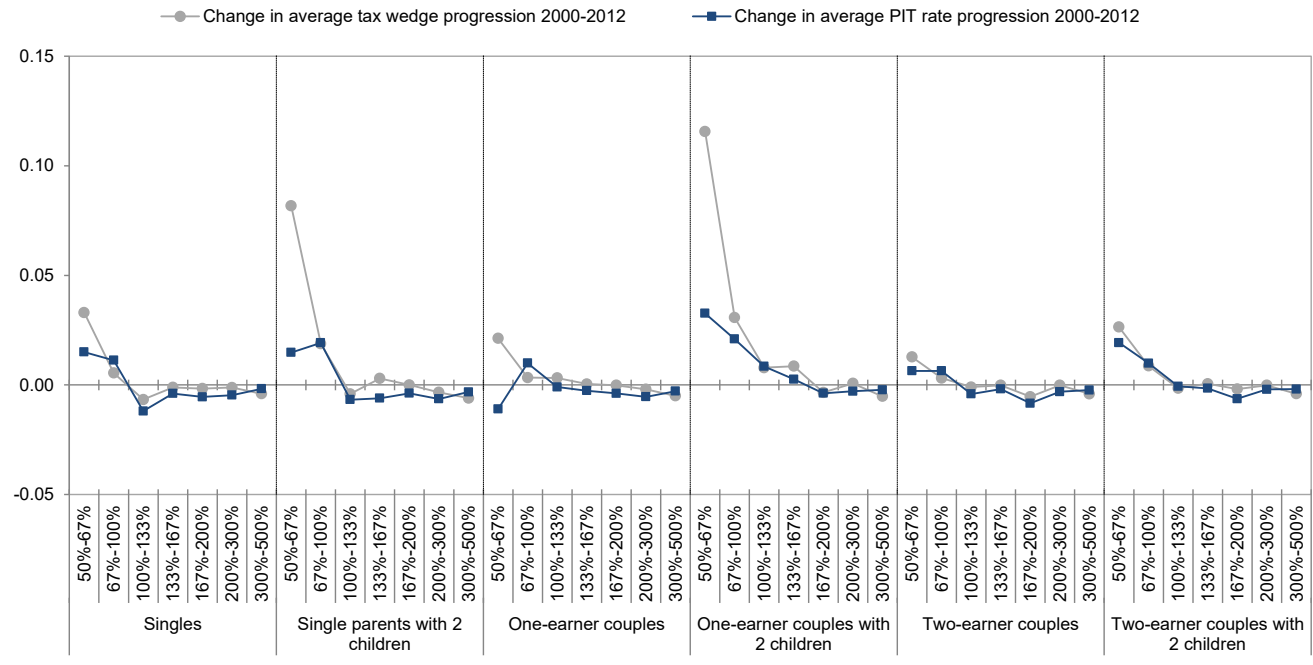

Source: OECD (2014), Taxing Wages 2014, OECD Publishing, Paris, http://dx.doi.org/10.1787/tax wages-2014-en.

\subsubsection{Lessons from Economic Surveys}

Increasing the exemption threshold

Progressive tax rates can contribute to income redistribution, but the setting of rate brackets poses a challenge for tax policymakers. Tax reforms during the past two or three decades have, among other things, reduced the number of personal income tax brackets and the top rates. Concomitantly, income thresholds at which each progressively higher rate applies have in some countries affected wider swaths of taxpayers. The first threshold, below which income is exempt from income tax can adversely impact lower-income households as their taxable income breaches the threshold. Also, the top marginal tax rate can often apply at relatively low-income levels. Figure 10 shows the top statutory marginal income tax rate in countries and relative income (specifically, multiples of the average wage in each country) at which the top rate kicks in. 
Figure 10. Top marginal tax rates and corresponding thresholds 2016

Panel A. Top marginal and statutory tax rates ${ }^{1}$

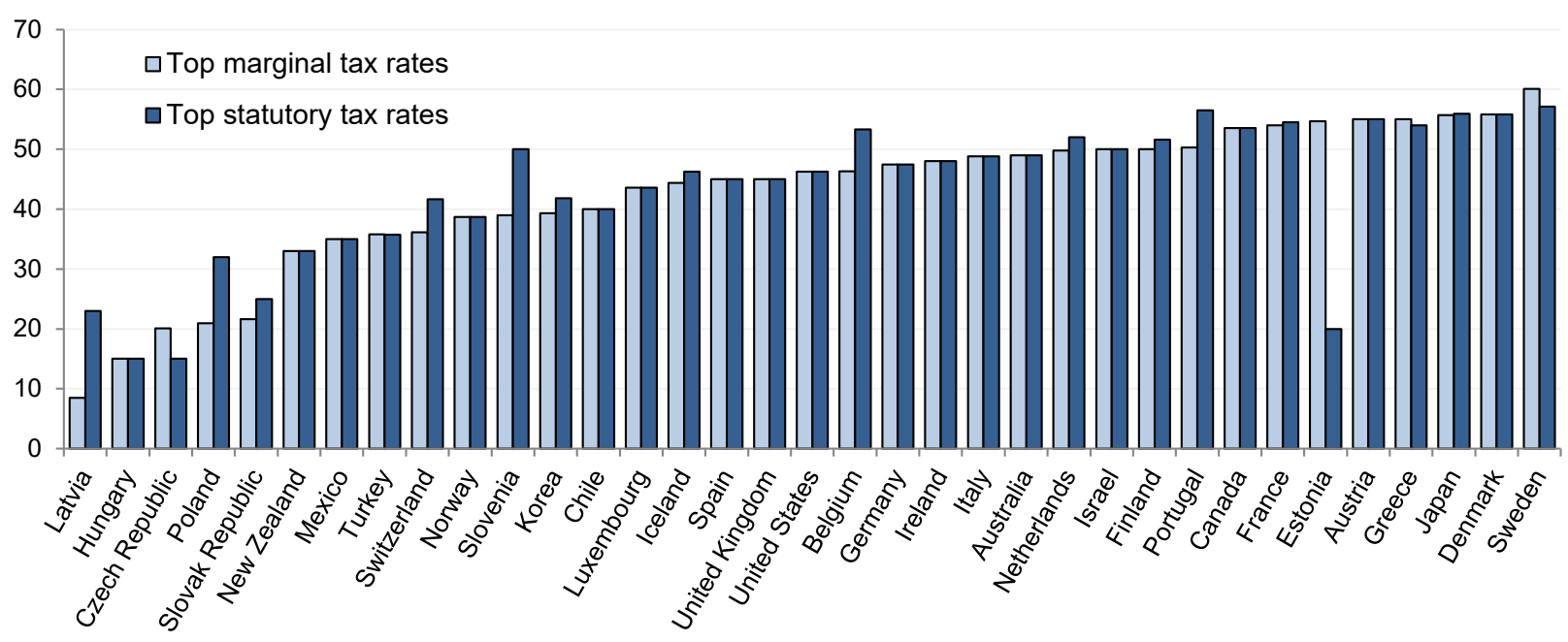

Panel B. Top statutory threshold, expressed as multiple of the average wage ${ }^{2}$

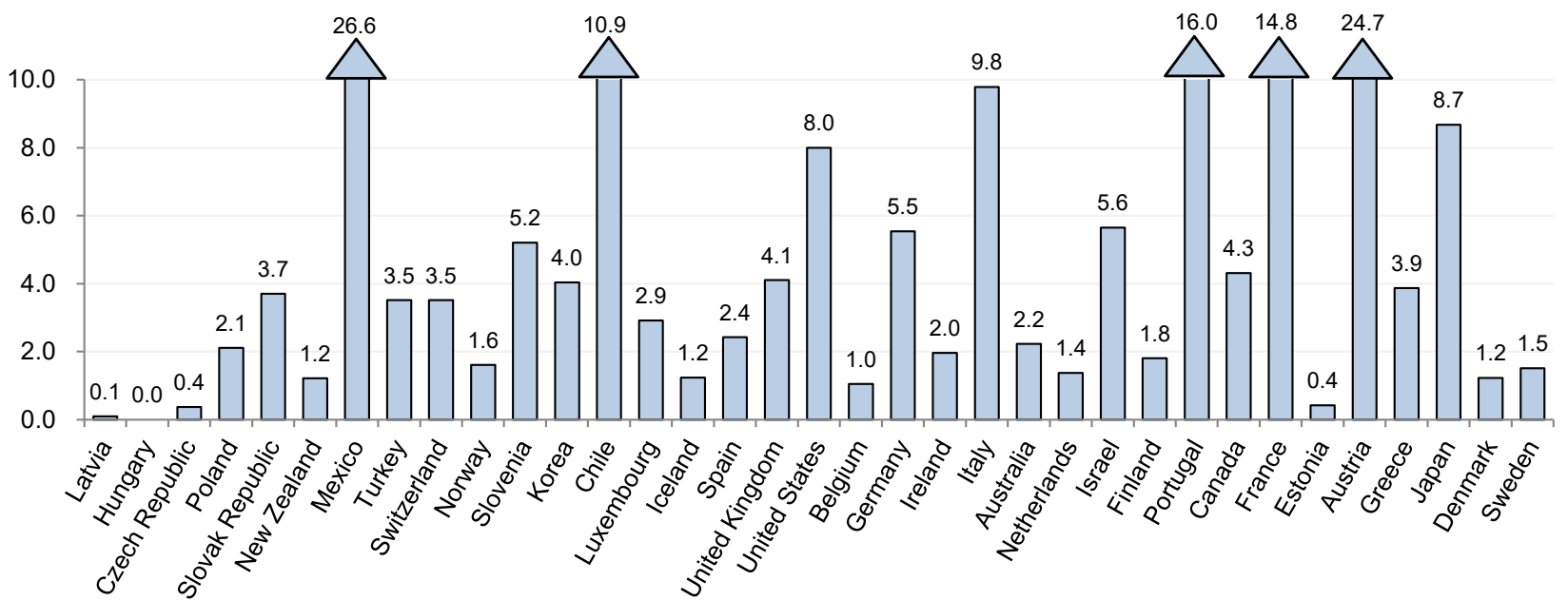

1. The top statutory rate refers to the maximum rate of personal income tax that would apply in the absence of any base-reducing tax preferences. The top marginal tax rate takes into account the fact that not all income is subject to income taxation. The top marginal tax rate refers to personal income tax and does not cover social security contributions.

2. A threshold as a fraction of the average wage below one typically reflects the presence of a flat (single rate) personal income tax that takes effect at relatively low income, as in the Czech Republic, Estonia, Hungary and Latvia.

Source: OECD (2018), "Personal income tax: Top statutory and marginal tax rates for employees", OECD Tax Statistics (database), http://dx.doi.org/10.1787/data-00806-en (accessed on 11 April 2018).

Low thresholds for exempt income can undermine active labour market participation. As work-related incentives (e.g., earned-income tax credits) tend to be withdrawn with rising income, low income tax thresholds can push taxpayers more rapidly into a taxpaying status, causing a spike in their marginal tax rate. These high effective marginal tax rates can have disincentive effects on continued labour market participation. Increasing the tax-free threshold, as were urged authorities in Australia, Belgium, Denmark, France, Japan and Sweden in the reviewed OECD Economic Surveys, would be favourable to inclusive growth. 
In Australia, the interaction of the transfer system and the low level of the threshold doubled the number of taxpayers facing a marginal effective tax rate of $50 \%$ during the decade ending in 2007 (OECD Economic Surveys Australia, 2010). These high rates were especially detrimental to the labour supply choices of second earners. Tax reforms in Belgium during the 2000s improved incentives for low-income workers, but the exempt threshold left two-thirds of taxpayers at a marginal tax rate over 40\% (OECD Economic Surveys Belgium, 2009). In Japan, the principal earner in a household is allowed a sizeable tax deduction as long as the spouse's income remains below a specified limit, which provides a strong incentive for female workers to limit hours worked. The Czech Republic's tax reform during the late 2000s by contrast raised the threshold of the new flat tax that was introduced (OECD Economic Surveys the Czech Republic, 2008 and 2010). India and Indonesia appeared to have broadly appropriate combinations of low marginal tax rates and high thresholds (OECD Economic Surveys India, 2017; OECD Economic Surveys Indonesia, 2012).

Individualising income taxation

The definition of the tax unit strongly affects the impact of personal income taxation on secondary workers. Where the tax unit is the household rather than the individual, spousal incomes can raise the average tax rate for the household by virtue of the extra work pushing the household into a higher marginal tax bracket. ${ }^{11}$ For instance, both France and Germany rely on systems of joint taxation of a married couple, as opposed to the more widely prevailing individual taxation used in most countries. These schemes tend to create disincentives for second workers due to higher tax rates than under individual taxation. Ireland's move in 2000 from full to partial joint assessment has been linked with a 5 percentage point increase in the employment rate of married women (Doorley, 2018). Beyond a simple policy choice of redefining the tax unit, Germany faces a unique challenge due to the fact that individual taxation would likely be unconstitutional. The German constitutional court ruled in 1957 that a married couple should not be disadvantaged relative to a non-married couple and that an equal share of total household earnings belongs to each person in a marriage. Reforms led to the current scheme, which satisfies the constitutional requirement.

\section{Dual income tax schemes can be associated with leakages}

The globalisation of financial markets has naturally been accompanied by an increase in the mobility of financial capital. In the interest of minimizing revenue losses due to potential capital outflows, a number of countries (notably the Nordic countries) have introduced dual income tax systems whereby the tax rate on capital income is lowered relative to the tax rate on labour income. While improving the efficiency of capital investment, dual income tax systems also create incentives for high-income earners to reclassify labour earnings as capital income. Procedures to minimise tax-arbitrage inevitably complicate the tax system, increasing compliance costs. Such incentives could more effectively be reduced by reducing the average tax rates on high-income earners, an approach that would be more easily implemented if revenue could be shifted to less distortive tax bases without reducing overall progressivity.

11. Another way of stating this is that in a two-worker household, the second worker does not benefit from the tax-free amount or the lower marginal tax rates in a progressive tax schedule. Therefore, the second worker faces a higher marginal tax rate at low earnings. Child care costs, where relevant, add further to the disincentive to enter active employment. 
Tax expenditures

The income tax systems of OECD countries are replete with base narrowing tax expenditures that in the aggregate cause tax rates to be higher than otherwise. The scale and scope of tax expenditures varies across countries, but they have been estimated to have reached close to a third of central government personal tax receipts in Canada in 2004 and the United States in 2008 (OECD, 2010b). The pervasiveness of the problem is such that recommendations for base-broadening through the elimination of tax expenditures were featured in every $O E C D$ Economic Survey reviewed for this paper. To be sure, not all tax expenditures are undesirable, because some can be an effective means of promoting public goals. But many are distortive and poorly targeted, or would not be assured of legislative approval if they competed with other priorities through the formal budget process. One of the most prevalent tax expenditures is the favourable treatment afforded owner-occupied housing. Virtually no country taxes the implicit rental income associated with owner-occupied housing due to ostensible estimation difficulties, while most countries nonetheless allow the deductibility of mortgage interest costs. OECD Economic Surveys regularly urged countries to tax imputed rental incomes or, at a minimum, to eliminate the deductibility of mortgage interest. Other prominent tax expenditures are deductions for contributions to retirement plans and health insurance premiums, as well as for charitable donations, and the exclusion of employer provided health insurance from the personal income tax base.

Tax expenditures in personal income tax systems are enduring despite their general harmfulness to inclusive growth. First, and perhaps most harmfully, they require tax rates to be higher than otherwise, including at low levels of income where high marginal tax rates-including from benefit withdrawals - are especially harmful to the neediest of society. Second, as statutory marginal tax rates rise with taxable income, tax allowances (in contrast to tax credits) are of greater value to upper income households, thereby reversing some of the progressivity desired in the first place. Third, they are also horizontally inequitable when two households with the same ability to pay face different tax burdens solely because one benefits from a tax preference while the other does not.

Social security contributions as taxes

In principle, as they are linked to current or future benefits, social security contributions need not per se distort labour markets in the same way as an income tax or a pure payroll tax. Where the contribution-benefit linkage is not strong, as with health insurance or family allowances, the contributions can have similar effects as a personal income tax. In most countries, a portion of the total social security contribution is paid by employers. In the interest of boosting employment of low-skilled workers, many countries (Belgium, Austria, France, Hungary, Portugal and Sweden) reduced employers' social security contributions for people with low income. Although such targeted cuts may have positive employment effects for low-income workers, if made permanent, they leave a long-term funding gap for social security and social insurance benefits. One option for replacing the lost revenue includes broadening the contribution base. For most countries, this would require lifting the cap on earnings on which contributions are paid. Other things equal, however, this would increase the progressivity of social security contributions. An alternative would be to formally replace the lost revenues with funding from another tax base, such as income from capital. This, however, would weaken the link between benefits and contributions. 
The two-way causality of high taxes and large informal sectors

Although underground economies exist in most countries, middle income emerging economies are confronted with a greater challenge. A combination of a narrow tax base (whether for indirect or direct taxation) and a high average tax rate is both a cause and a consequence of a large informal sector, as is the case in Indonesia, India, and Turkey. For instance, due to the large scale of the informal sector in Turkey, the relatively low tax yield is nonetheless a heavy burden on the formal sector, where regressive excise duties loom large. High social security contributions contribute to a high tax wedge and are an impediment to employment and to the formalisation of the economy. Attracting workers and firms into the formal sector ultimately hinges on providing public services that are broadly seen as good value for money. As stressed in OECD Economic Surveys, a first priority is, however, to boost administrative and enforcement capacity to broaden as much as possible the formal sector tax base.

\subsection{Corporate income taxation}

\subsubsection{Guidance from cross-country evidence}

The taxation of corporate income can affect income growth through a number of channels. First, much of capital formation occurs through corporate investment that is importantly, though not solely, affected by the after-tax cost of capital and the expected rate of return on investment. By reducing the after-tax rate of return, corporate taxes have a negative impact on corporate investment. Summarizing the empirical findings from firm-level and industry-level studies, Johansson et al. (2008) stress the considerable evidence that corporate taxes, by raising the taxadjusted cost of capital, are harmful to investment, although young, often less profitable, enterprises are less sensitive than older, established firms. Second, productivity is harmed through corporate taxes that, as too often designed, distort relative prices and, in turn, cause a sub-optimal allocation of investment (including less investment in innovative activities) that lead to lower productivity growth than otherwise. In addition, given the complexities of corporate taxation, high compliance costs divert resources from more valuable uses.

Whether or not reductions in the effective corporate income tax rate are or would be harmful to inequality hinges both on the ultimate growth impacts mentioned above and on the incidence of corporate taxes. In a closed economy, the extent to which the tax reduces compensation to capital depends on the substitutability of labour for capital. By contrast, in an open economy, the mobility of capital implies that wage earners bear the brunt of corporate taxes. The past several decades have witnessed a remarkable degree of trade and investment liberalisation. The increased openness may explain in part the robust empirical results obtained by Akgun et al. (2017) of no statistically significant impact on inequality from revenue-neutral cuts in marginal effective corporate tax rates. Furthermore, the results corroborate and support the oft-repeated OECD recommendations in favour of a low-rate, broad-based approach to corporate taxation.

An underlying consensus among policymakers about the favourable effects on inclusive economic growth likely underpins in part the corporate tax reforms that have been undertaken over the past several decades. ${ }^{12}$ These have reduced effective corporate taxation (even if corporate tax receipts have remained relatively stable as a share of GDP). Reforms tended to focus on base broadening and statutory rate cuts, along with reforms aimed at reducing the

12. The widespread cuts in statutory corporate tax rates also reflect the effects of so-called "tax competition." 
dispersion in the effective tax rate across assets and industries. Thus, statutory corporate tax rates have fallen in all but one OECD country (Figure 11). Over time, estimated marginal and average effective corporate tax rates have also fallen in most countries.

Figure 11. Changes in statutory corporate tax rates

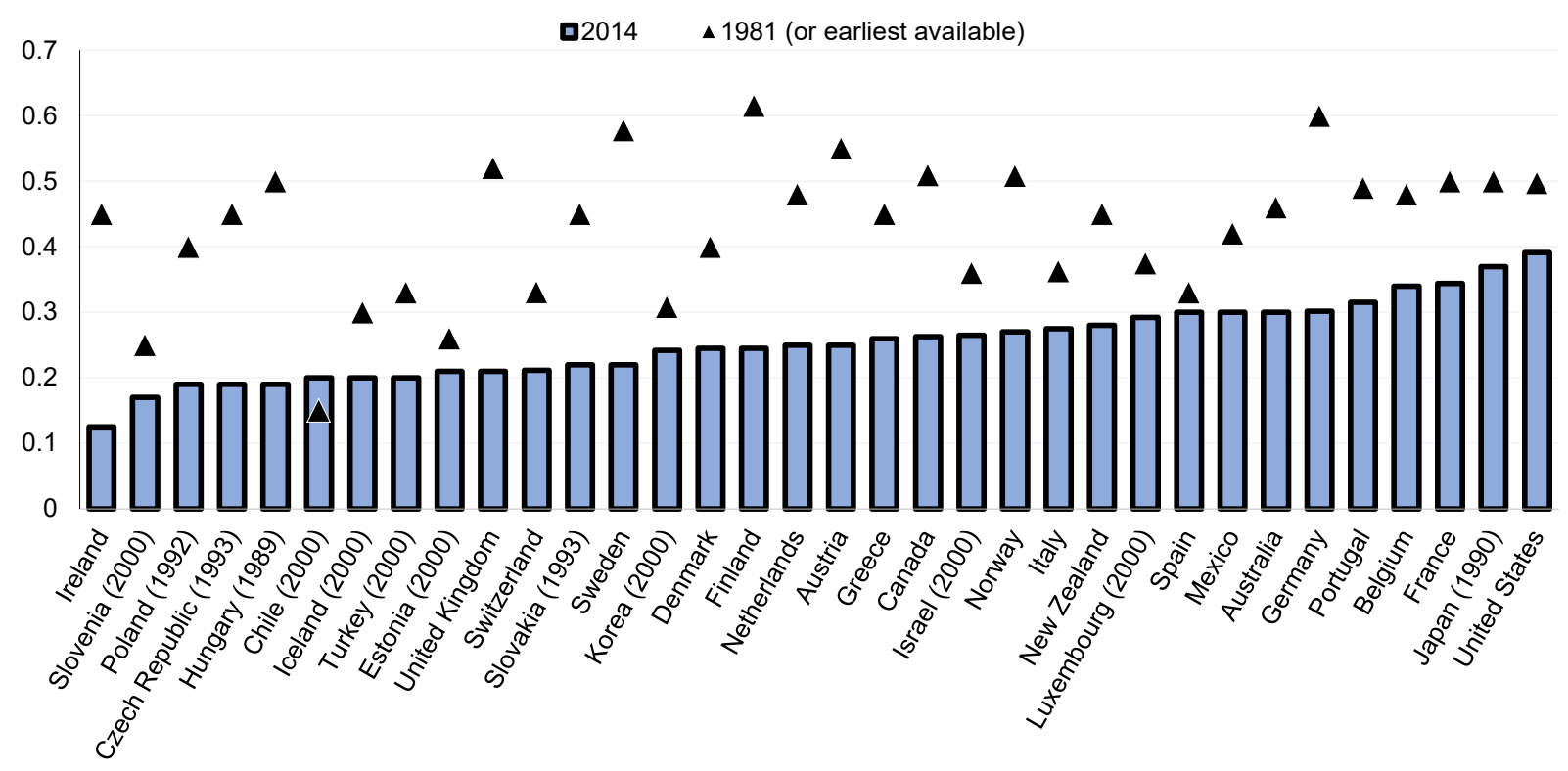

Source: OECD (2018), "Corporate income tax: Corporate income tax rates", OECD Tax Statistics (database), http://dx.doi.org/10.1787/7cde787f-en.

\subsubsection{Lessons from Economic Surveys}

Tax preferences for SMEs

Many countries provide tax-based incentives to small and medium enterprises (SMEs), a practice that may in many instances be on balance harmful to employment growth (OECD, 2009). Since, in the aggregate, small businesses are the principal source of employment, governments have an understandable desire to avoid tax (and other) policies from disadvantaging the small business sector. Proponents of reduced tax rates for SMEs invoke a variety of justifications (OECD, 2015), including market failure (i.e. absent reduced tax rates society would be deprived of positive spill-over benefits from investments by SMEs) and offsets for other government policies that are burdensome on small businesses (e.g. financial market policies or regulatory restraints). For start-up companies with little or no profit, tax incentives are of little value. By contrast, established SMEs may be deterred from expanding the enterprise in order to preserve their tax benefits. Thus, Belgium, Korea, Mexico, Poland, Spain and Switzerland were urged to give priority to eliminating such preferences and to instead broaden the overall corporate tax base to facilitate statutory rate reductions for all companies.

\section{Sub-central government corporate taxes can be an obstacle lowering CIT}

Sub-central governments in some countries also impose corporate taxes. Sub-central government dependency on corporate income tax revenues can be an obstacle to further shifting the tax mix toward a less distortive one. Company locational decisions are of course influenced by a range of determinants (local public services, labour supply and infrastructure, etc.), including taxation. Thus, inter-jurisdictional competition can play a key role in minimising local corporate 
taxes. But given the volatility of corporate tax revenues and the limited abilities of local governments to run counter-cyclical policies, a strong case can be made to centralise corporate taxation, offsetting the revenue losses at lower levels of government by increased central government transfers. Alternatively, revenue could be shifted to a less distortive base such as property taxes. In Germany, reducing further overall corporate and business taxation would warrant, as argued in a number of OECD Economic Surveys, replacing the local trade tax (which piggybacks on the corporate income tax base) with revenues from less mobile and distortive taxes.

\section{Political opposition looms large}

Although the corporate income tax has increasingly come to be viewed as potentially harmful to growth, there are solid reasons why governments should retain it. First, there is considerable political support for maintaining corporate taxes on grounds that shareholders of large corporations are predominantly wealthy. Second, in the absence of the CIT, capital income earned by non-residents would not be taxed in the source country. Third, it is also true that since societies bestow a number of special privileges on corporations, not least the limited liability of shareholders, companies should contribute to funding public purposes. Thus, while further reforms to reduce aspects of corporate taxation that are harmful to inclusive growth are warranted, progress made in reforming corporate tax systems in many countries over the past decades suggest that further tax shifts favourable to inclusive growth are more likely to entail shifts from personal income taxation toward immovable property and consumption.

\section{The way forward}

The previous section has sought to illustrate opportunities for and obstacles to tax reforms that would shift taxation toward one that would be more supportive of inclusive growth. The presentation and analyses are admittedly far from exhaustive. Countries' revenue systems are complex, and national specificities are remarkably varied. Box 5 highlights two examples-the Czech Republic and Sweden-of relatively recent efforts to alter the tax mix. The discussion is intended to illustrate real world limits to some types of reforms that would otherwise be advantageous to inclusive growth. Lessons learned from this joint review of cross-country empirical evidence and country experiences for each major tax category were summarised in the introduction. Synthesizing those findings offers some potential and inter-related guidance for advancing more inclusive tax policies.

First, shaping tax policies to achieve more inclusive growth requires that authorities in many countries reconsider attitudes toward, and approaches to addressing, potential regressivity of some taxes. As noted at the outset of this paper, what matters is not the vertical inequity of any specific parts of a tax system, but rather the overall redistribution that is achieved via the totality of the government's tax and spending programmes. OECD Economic Surveys are replete with sound tax policy advice to improve economic performance via less inefficient taxation combined with direct means-tested compensation to poorer households where warranted. Notwithstanding, governments are by and large slow to opt for and implement more efficient taxes and more effective safety nets. Thus, effecting a sustained transformation of a country's tax system designed to improve inclusive growth first requires an a priori acceptance of the superiority of this approach.

Second, and relatedly, OECD policy advice to advance the above approach requires in most instances greater specificity on the strategy to achieve the reform. The cross-country evidence on the ranking of the major taxes served as the foundation for major tax policy 
recommendations proposed in essentially all the OECD Economic Surveys reviewed for this synthesis paper. Similarly, direct compensation for any tax's regressivity is systematically recommended. And yet, Surveys rarely if ever offer more specific, country-based recommendations for achieving the more direct, means-tested option.

\section{Box 5. Country examples of efforts to change the tax mix}

Improving the tax mix understandably tends to be a slow, incremental process. In turn, aggregate measures such as ratios of major tax categories to GDP will reveal much less than detailed and careful analysis of key parameters of different taxes that affect their efficiency and fairness. Many of the countries whose tax systems were assessed in $O E C D$ Economic Surveys during the past decade made progress in the pursuit of greater efficiency and fairness, even if aggregate measures do not reflect fully those reforms. Among the countries reviewed over the past decade, two examples of this incrementalism—the Czech Republic and Sweden-are illustrative.

\section{The Czech Republic}

The Czech Republic undertook important tax reforms during the mid-2000s designed to promote growth and employment by simplifying the tax system, lowering tax while also broadening tax bases, gradually shifting toward greater reliance on indirect taxation. Importantly, the reforms were designed to avoid sacrificing redistribution. All the while noting that much remained to be done to further improve the tax system, "[t]he reform made the tax system more transparent and was broadly consistent with OECD recommendations concerning pro-growth tax reform." (2010 Economic Survey of the Czech Republic, p. 73). The reforms included:

- Introduction of a flat-rate personal income tax at $15 \%$ on "super-gross" income (essentially, full employee compensation including employer social security contributions) imposed beginning at a high threshold, accompanied by increased tax credits for a non-earning spouse and children.

- A reduction in the corporate income tax rate to $19 \%$, accompanied by some broadening of the base.

- A near doubling of the reduced VAT rate that was applied to a range of basic goods.

- A granting to municipalities of greater flexibility to set tax rates on real estate and non-agricultural land.

- Introduction of new environmental taxes on electricity, coal and other solid fuels, and natural gas.

Altogether, the reforms were estimated to have shifted the total tax burden slightly toward indirect taxation, with the share of indirect taxes rising by 0.8 percentage points in 2008. OECD empirical estimates by Akgun et al. (2017) suggest that these reforms, by lowering marginal effective tax rates on corporate income and, for many households, personal income, have had positive effects on output per capita and disposable incomes for most households. Meantime, however, there remained much room for further improvements, especially towards a greater contribution of the tax system to inequality reduction, including the need to focus on reducing marginal and average effective tax rates for well below-average earning two-worker households with children. Also, greater progressivity, without harm to labour supply incentives, was considered possible by lifting the ceiling on earnings subject to the social security contribution. In addition, further improvements to the corporate income tax were considered to be warranted, notably to increase the neutrality of treatment of debt and equity financing of investment.

\section{Sweden}

Since the mid to late-2000s, Sweden has adopted a number of tax measures aimed at improving work incentives and entrepreneurship, increasing the attractiveness of corporate investment, and strengthening environmental taxation. These reforms, together with reforms to the welfare state that helped contain social spending, helped Sweden move from second rank to seventh in terms of the share of total tax revenue in GDP. As a small open economy, an important concern for successive governments has been to align corporate taxation with the realities of financial globalization. In turn, the statutory corporate tax rate was reduced from just under $60 \%$ in the 1960 s to $22 \%$ currently, a level that is competitive with Sweden's Nordic neighbours. Thanks to base broadening measures, the share of corporate taxes in GDP increased slightly during the two decades to 2015. In a context of growing capital mobility, the wealth tax was abolished to help improve Sweden's competitiveness. As in other Nordic countries, Sweden has a dualincome personal income tax system whereby earned income is taxed at progressive rates while capital gains are subject to a flat rate of $30 \%$, except for pension savings that are taxed at $15 \%$. 


\section{Box 5. Country examples of efforts to change the tax mix (cont.)}

With capital taxation constrained by sustained globalization, the tax burden on labour income has remained high. Personal income taxation consists of both a municipal flat rate income tax that varies across municipalities, and a highly progressive state income tax that accrues to the central government. Total marginal tax wedge on labour (employee and employer social security contributions, personal income taxes, and consumption taxes) were still reaching close to $71 \%$ in the mid-2000s. Although lower for below average workers due to the high degree of progressivity in the state income tax system, the total tax wedge on labour was still no lower than $56 \%$ for incomes exceeding the basic personal deduction. Tax policies during the late 2000s were therefore focused on reforms to reduce the effective marginal tax rate, notably for low-income earners to promote activation in the labour market. Measures included the introduction in 2007 of an earned-income tax credit (EITC), which was increased in steps in 2008,2009 , and 2010. By reducing the effective marginal tax wedge on low-income earners, these reforms are likely to have boosted output per capita and household disposable incomes, especially so at the bottom (Akgun et al., 2017).

Notwithstanding its effectiveness elsewhere (e.g. the United States and Great Britain), the Swedish in-work tax credit was deemed (OECD Economic Survey of Sweden, 2008) to be less cost effective in expanding the labour force than the alternative of simply cutting the state income tax, notably by raising the threshold at which the state tax is paid.

Tilting the tax mix away from personal income toward consumption taxation remains constrained by an already high standard VAT rate. Indeed, at $25 \%$, Sweden's VAT rate is (together with Denmark and Norway) among the highest. However, reflecting the combination of reduced rates, exemptions and evasion, the VAT revenue ratio (57\%) (Annex Table 3) stands at about the OECD average. Thus, increasing VAT revenues requires a combination of increases in or elimination of the reduced VAT rates (together with direct compensation for low-income households) and strengthened compliance and enforcement.

Property taxes as a share of GDP are low in Sweden by international comparison. At $1 \%$ of GDP, Sweden's property tax receipts placed the country well below the OECD average of $2 \%$. This reflects policies directly favouring investment in owner-occupied housing, including a replacement of a value-based tax on immovable property prior to 2008 by a fixed, but indexed (though capped), municipal fee. This severed the link between the tax and market value and contributed to a decline in property tax revenues. "This reform was driven by a lack of public support for property taxation and increasing property taxes remains politically difficult." (OECD Economic Surveys: Sweden, 2008). Lower reliance on recurring property taxes as part of the tax mix is, however, likely to harm output per capita, due to the comparatively low economic distortions associated with these taxes (Arnold, 2008; Akgun et al., 2017). 


\section{References}

Akgun, O., B. Cournède and J-M. Fournier (2017), "The Effects of the Tax Mix on Inequality and Growth", OECD Economics Department Working Papers, No. 1447, OECD Publishing, Paris, http://dx.doi.org/10.1787/c57eaa14-en.

Albrizio, S., T. Koźluk and V. Zipperer (2014), "Empirical Evidence on the Effects of Environmental Policy Stringency on Productivity Growth," OECD Economics Department Working Paper, No. 1179, OECD Publishing, Paris, http://dx.doi.org/10.1787/5jxrinb36b40-en.

Arnold, J. (2008), "Do Tax Structures Affect Aggregate Economic Growth”, OECD Economics Department Working Papers, No. 643, OECD Publishing, Paris, http://dx.doi.org/10.1787/236001777843.

Arnold, J., B. Brys, C. Heady, A. Johansson, C. Schwellnus and L. Vartia (2011), "Tax Policy For Economic Recovery and Growth", The Economic Journal, 121.

Bozio, A., R. Dauvergne, B. Fabre, J. Goupille and O. Meslin (2012), "Fiscalité et Redistribution en France," Institut des Politiques Publiques, March 2012, www.ipp.eu/wpcontent/uploads/2011/11/fiscalite-redistribution-rapport-IPP-mars2012.pdf.

Blöchliger, H. (2015), "Reforming the Tax on Immovable Property", OECD Economics Department Working Papers, No. 1205, OECD Publishing, Paris, http://dx.doi.org/10.1787/5js30tw0n7kg-en.

Bloch, D., J.-M. Fournier, D. Gonzales and A. Pina (2016), "Trends in Public Finance: Insights from a New Detailed Dataset", OECD Economics Department Working Paper No. 1345, OECD Publishing, Paris, http://dx.doi.org/10.1787/4d3d8b25-en.

Brys, B., S. Perret, A. Thomas and P. O'Reilly (2016), "Tax Design for Inclusive Growth", OECD Taxation Working Papers, No. 26, OECD Publishing, Paris, http://dx.doi.org/10.1787/5jlv74ggk0g7-en.

Callan, T., Bercholz, M. and Walsh, J. (2017, July), "Income Growth and Income Distribution: a Long-Run View of the Irish Experience", Budget Perspectives, Dublin, Economic and Social Research Institute.

Causa, O. and M. Hermansen (2018)," Income Redistribution through Taxes and Transfers across OECD Countries," OECD Economics Department Working Papers, No. 1453, OECD Publishing, Paris, http://dx.doi.org/10.1787/bc7569c6-en.

Decoster, A., J, Loughrey, C. O'Donoghue and D. Verweft (210), "How Regressive are Indirect Taxes? A Microsimulation Analysis for Five European Countries," Journal of Policy Analysis and Management, Vol. 29, Issue 2.

Diamond, P.A. and J.A. Mirrlees (1971), "Optimal Taxation and Public Production", American Economic Review, Vol.61. 
Doorley, C. (2018, April), "Taxation, Work and Gender Equality in Ireland”, IZA Discussion Paper Series, Institute of Labor Economics.

Flues, F. and A. Thomas (2015), "The Distributional Effects of Energy Taxes," OECD Taxation Working Papers, No. 23, OECD Publishing, Paris, http://dx.doi.org/10.1787/5js1qwkqarbv-en.

Flues, F. and K. van Dender (2017), "The Impact of Energy Taxes on the Affordability of Domestic Energy", OECD Taxation Working Papers, No. 30, OECD Publishing, Paris, http://dx.doi.org/10.1787/08705547-en.

Fournier, J. and $\AA$. Johansson (2016), "The Effect of the Size and the Mix of Public Spending on Growth and Inequality", OECD Economics Department Working Papers, No. 1344, OECD Publishing, Paris, http://dx.doi.org/10.1787/f99f6b36-en.

Hall, R. E. (1988), "Intertemporal Substitution in Consumption”, Journal of Political Economy, 96.

Johansson, Å., C. Heady, J. Arnold, B. Brys and L. Vartia (2008), "Taxation and Economic Growth", OECD Economics Department Working Papers No. 620, OECD Publishing, Paris, http://dx.doi.org/10.1787/241216205486.

Leahy, E., S. Lyons and R. Tol (2011), "The Distributional Effects of Value Added Tax in Ireland", The Economic and Social Review, Vol. 42(2), pp 213-235.

Marron, D, B. and A. C. Morris (2016), "How to Use Carbon Tax Revenues," Tax Policy Center, www.brookings.edu/wpcontent/uploads/2016/07/howtousecarbontaxrevenuemarronmorris.pdf

McKibbin, W. J., A. C. Morris, P. J. Wilcoxen and Y. Cai (2015), "Carbon Taxes and U.S. Fiscal Reform", National Tax Journal, No. 68 (1): 139-56.

O'Donoghue, C., M. Baldini and D. Mantovani (2004), "Modelling the Redistributive Impact of Indirect Taxes in Europe: An Application of EUROMOD", EUROMOD Working Paper, No. EM7/01.

OECD (2009), Taxation of SMEs: Key Issues and Policy Considerations, OECD Publishing, Paris, www.oecd.org/tax/tax-policy/taxation-of-smes-9789264024748-en.htm.

OECD (2010a), Environmental Taxation, A Guide for Policymakers, OECD Publishing, Paris, www.oecd.org/env/tools-evaluation/48164926.pdf.

OECD (2010b), Tax Expenditures in OECD Countries, OECD Publishing, Paris, www.oecd.org/gov/budgeting/taxexpendituresinoecdcountries-oecdpublication.htm.

OECD (2010c), Choosing a Broad Base-Low Rate Approach to Taxation, OECD Tax Policy Studies No. 19, OECD Publishing, Paris, www.oecd.org/ctp/tax-policy/choosing-a-broadbase-low-rate-approach-to-taxation-9789264091320-en.htm.

OECD 2013, Addressing Base Erosion and Profit Shifting, OECD Publishing, Paris, http://dx.doi.org/10.1787/9789264192744-en. 
OECD/KOPF (2014), "The Distributional Effects of Consumption Taxes in OECD Countries", OECD Publishing, Paris, http://dx.doi.org/10.1787/9789264224520-en.

OECD (2015), Taxation of SMEs in OECD and G20 Countries, OECD Tax Policy Studies, No. 23, OECD Publishing, Paris, http://dx.doi.org/10.1787/9789264243507-en.

OECD (2016a), Consumption Tax Trends 2016, OECD Publishing, Paris, http://dx.doi.org/10.1787/ctt-2016-en.

OECD (2016b), Effective Carbon Rates: Pricing $\mathrm{CO}_{2}$ through Taxes and Emissions Trading Systems, OECD Publishing, Paris, http://dx.doi.org/10.1787/9789264260115-en.

OECD(2017), Revenue Statistics 1965-2015, OECD Publishing, Paris, http://dx.doi.org/10.1787/9789264283183-en.

OECD (2018), Taxing Energy Use 2018: A Companion to the Taxing Energy Use Database, OECD Publishing, Paris, http://dx.doi.org/10.1787/9789264289635-en.

Pestel, N. and E. Sommer (2017), "Shifting Taxes from Labour to Consumption: More Employment and More Inequality," Review of Income and Wealth, Vol. 63, Issue No. 3.

Rosen, H. and T. Gayer (2010), Public Finance, McGraw Hill.

Ruiz, N. and A. Trannoy (2008), "Le Caractère Régressif des Taxes Indirectes: Les Enseignements d'un Modèle de Microsimulation”, Economie et Statistique, No. 413.

Sörensen, P.B. (2010), "Swedish Tax Policy: Recent Trends and Future Challenges", Report of the Expert Group on Public Economics, No. 4, https://eso.expertgrupp.se/wpcontent/uploads/2013/07/ESO-2010 4-del-1-till-webben.pdf.

Summers, L. H. (1982), “Tax Policy and the Return to Savings”, NBER Working Papers No. 995.

Thomas, A. (forthcoming), "Distributional Aspects of VAT in OECD Countries," OECD Taxation Working Papers, OECD Publishing, Paris. 


\section{Annex A}

Table A1. Tax reform recommendations in OECD Economic Surveys

2008-17

\begin{tabular}{|c|c|c|}
\hline Country & Chapter title & Main Recommendations \\
\hline $\begin{array}{l}\text { Australia } \\
(2014)\end{array}$ & $\begin{array}{l}\text { "Improving taxes and } \\
\text { transfers" }\end{array}$ & $\begin{array}{l}\text { - } \text { Shift away from income taxes } \\
\text { - } \text { Reduce preferential treatment under GST } \\
\text { - } \text { medium-term } \\
\text { - } \text { Reduce transactions taxes and consider greater use of recurrent } \\
\text { property taxes } \\
\text { - } \text { Lower corporate income tax rate } \\
\text { - Envisage taxation of supernormal profits tax in natural resource } \\
\text { - } \text { sector } \\
\text { - } \text { Make transport policy greener by indexing retail fuel charges } \\
\end{array}$ \\
\hline $\begin{array}{l}\text { Belgium } \\
(2009)\end{array}$ & $\begin{array}{l}\text { "How to reform the tax } \\
\text { system to enhance } \\
\text { economic growth" }\end{array}$ & $\begin{array}{l}\text { - Increase taxation of owner-occupied housing via tax on imputed } \\
\text { rent and/or reduced mortgage interest deduction } \\
\text { - } \text { Reduce average tax on labour and remove spikes in effective } \\
\text { marginal tax rates } \\
\text { - } \text { Complete the full tax separation of spouses } \\
\text { - } \text { Broaden income tax base to lower rates } \\
\text { - } \text { Eliminate all reduced VAT rates } \\
\text { - Increase taxation of fuels, particularly diesel }\end{array}$ \\
\hline Brazil (2009) & $\begin{array}{l}\text { "Reforming indirect taxes } \\
\text { and labour levies" }\end{array}$ & $\begin{array}{l}\text { - Reduce threshold for eligibility for presumptive taxation } \\
\text { - Shift all ICMS (Brazil's main VAT) to destination base to eliminate } \\
\text { predatory horizontal competition } \\
\text { - Make new ICMS rates as uniform as possible by avoiding } \\
\text { exemptions } \\
\text { - Eliminate para-fiscal levies on labour income } \\
\text { - Reduce employers' social security contributions } \\
\end{array}$ \\
\hline $\begin{array}{l}\text { Canada } \\
\text { (2008) }\end{array}$ & $\begin{array}{l}\text { "Tax reform for efficiency } \\
\text { and fairness" }\end{array}$ & $\begin{array}{l}\text { - } \text { Complete harmonization of VAT across provinces } \\
\text { - } \text { Consider introduction of a federal GHG emissions tax } \\
\text { - } \text { prope more use of property taxes by municipalities while reducing } \\
\text { - } \quad \text { Target in-work tax credits on low-income workers and phase out } \\
\text { more gradually to reduce high effective marginal tax rate } \\
\text { - } \text { Broaden personal income tax base and reduce rates } \\
\text { - } \text { then reduce combined federal-provincial rate to close to } 20 \%\end{array}$ \\
\hline $\begin{array}{l}\text { Columbia } \\
\text { (2015) }\end{array}$ & $\begin{array}{l}\text { "Making tax policies more } \\
\text { efficient, fair and green" }\end{array}$ & $\begin{array}{l}\text { - Gradually reduce corporate income tax, phasing our net wealth tax } \\
\text { on firms and eliminating VAT in investments } \\
\text { - Broaden corporate income tax base } \\
\text { - Increase progressivity of personal income tax by taxing dividends } \\
\text { and eliminating regressive deductions } \\
\text { - Strengthen compliance to reduce evasion } \\
\text { - Increase standard VAT rate and broaden base by eliminating } \\
\text { exemptions on non-essential items } \\
\text { - Adjust tax rates on transport fuels and eventually introduce a carbon } \\
\text { tax }\end{array}$ \\
\hline
\end{tabular}


Table A1. Tax reform recommendations in OECD Economic Surveys (cont.)

\begin{tabular}{ll}
\hline Czech & "Ensuring fiscal \\
Republic & sustainability: assessing \\
$(2008$ and & recent tax and public \\
$2010)$ & spending reforms" \\
& \\
& "Further advancing pro- \\
& growth tax and benefit \\
& reform"
\end{tabular}

\begin{tabular}{ll}
\hline $\begin{array}{l}\text { Denmark } \\
(2008)\end{array}$ & "Tax reform, hours worked \\
& and growth"
\end{tabular}

- Reduce effective tax wedge for low-income workers

- Increase the progressivity of the system

- Adopt a GHG emissions tax

- Consider reductions in employers' social security contributions by employers for low-income workers

- Make corporate income tax more neutral with respect to investment in different assets

- Levy VAT at single rate and reduce to minimum exemptions

- Increase real estate tax and link to market prices

- Reduce high marginal tax rates that apply to incomes just above average fulltime earnings

- Accompany any further expansions of in-work tax credit with reductions in other benefits

- Shift burden away from labour and corporate income toward immovable property

- Streamline tax expenditures

- Further lower marginal tax rates on higher incomes

- Raise tax rates on coal and diesel

Estonia "Fiscal policy: Avoiding

(2011) pro-cyclicality and safeguarding sustainability"

- Remove distortive personal income tax exemptions, notably mortgage interest payments

- Increase environmental taxation by aligning tax on GHG emissions

- Increase taxation of immovable property by increasing assessed values to market values and by eliminating exemption for land

- Reduce the high tax wedge on labour targeting reductions in direct taxes on low-income workers

- Reduce number of preferential VAT rates

\begin{tabular}{|c|c|c|}
\hline $\begin{array}{l}\text { Finland (2008 } \\
\text { and 2018) }\end{array}$ & $\begin{array}{l}\text { "Setting tax policies that } \\
\text { support the Nordic model" }\end{array}$ & $\begin{array}{l}\text { - Continue to lower taxation of labour, giving priority to lowering the } \\
\text { top marginal tax rate } \\
\text { - Increase property taxation by setting property assessments equal to } \\
100 \% \text { of market value, raising the minimum rate and eliminating the } \\
\text { maximum rate } \\
\text { - Eliminate the share of corporate income tax flowing to municipalities } \\
\text { - Broaden the VAT base by eliminating the reduced rate and enabling } \\
\text { lower standard rate } \\
\text { - Look for ways to broaden the corporate tax base and lower the rate } \\
\text { - Harmonise emissions tax rate across sectors to reduce GHG } \\
\text { emissions, increase environmentally-related taxes, and phase out } \\
\text { environmentally harmful subsidies }\end{array}$ \\
\hline $\begin{array}{l}\text { France } \\
\text { (2013) }\end{array}$ & $\begin{array}{l}\text { "The efficiency and equity } \\
\text { of the tax and transfer } \\
\text { system" }\end{array}$ & $\begin{array}{l}\text { - Broaden tax bases by phasing out tax expenditures } \\
\text { - Turn taxe foncière into a tax on imputed rents by regularly updating } \\
\text { property values } \\
\text { - } \text { Align capital gains taxation of owner-occupied housing with capital } \\
\text { gains tax rate on other assets } \\
\text { - Tax bequests and gifts based on lifetime amounts } \\
\text { - Phase out reduced VAT rates and compensate poor with cash } \\
\text { - } \text { payments } \\
\text { - Adopt individual-based personal income taxation } \\
\text { - Cut social security contributions by shifting the financing of benefits } \\
\text { - to general revenue }\end{array}$ \\
\hline
\end{tabular}


Table A1. Tax reform recommendations in OECD Economic Surveys (cont.)

\begin{tabular}{|c|c|c|}
\hline $\begin{array}{l}\text { Germany } \\
(2008)\end{array}$ & $\begin{array}{l}\text { "Preserving past } \\
\text { achievements in fiscal } \\
\text { policy and making the tax } \\
\text { system more efficient" }\end{array}$ & $\begin{array}{l}\text { - Go further in cutting statutory corporate tax rates and avoid } \\
\text { differentiating base-broadening by company size } \\
\text { - } \text { Consider abolishing local trade tax } \\
\text { - } \text { Raise property tax and apply to actual prices } \\
\text { - } \text { Move toward individual taxation } \\
\text { - } \text { Phase out reduced VAT rates } \\
\end{array}$ \\
\hline India (2017) & $\begin{array}{l}\text { "Making income and } \\
\text { property taxes more } \\
\text { growth friendly and } \\
\text { redistributive" }\end{array}$ & $\begin{array}{l}\text { - } \text { Gradually reduce statutory corporate income tax rate } \\
\text { - Reconsider personal income tax concessions that favour rich } \\
\text { taxpayers } \\
\text { - Enable local governments to raise more revenue from recurrent } \\
\text { taxes on immovable property and introduce inheritance tax } \\
\text { - Replace dividend distribution tax with traditional dividend } \\
\text { withholding tax and lower corporate tax rate on foreign investors to } \\
\text { resident rate }\end{array}$ \\
\hline $\begin{array}{l}\text { Indonesia } \\
(2012)\end{array}$ & "Improving the tax system" & $\begin{array}{l}\text { - Continue to expand number of taxpayers subject to personal } \\
\text { income tax } \\
\text { - Subject fringe benefits to income taxation and move toward equal } \\
\text { treatment of interest and dividend incomes } \\
\text { - Reconsider tax incentives and tax holidays for sectors or select } \\
\text { investment projects } \\
\text { - Move resource-sector fiscal regime to a system of taxation of rents } \\
\text { - Phase out exemptions from VAT } \\
\text { - Introduce a carbon tax } \\
\text { - Update property value registry to increase revenue from immovable } \\
\text { property taxation }\end{array}$ \\
\hline Israel (2013) & $\begin{array}{l}\text { "How to improve taxes and } \\
\text { transfers" }\end{array}$ & $\begin{array}{l}\text { - Increase excise tax on fuels to reflect carbon emissions } \\
\text { - Avoid increases in tax wedge on low-income labour } \\
\text { - Reduce tax credits that largely benefit middle and upper-income } \\
\text { - } \text { earners } \\
\text { - Refrain from further raising the corporate income tax rate } \\
\text { Ensure taxation is adequate in immobile sectors }\end{array}$ \\
\hline Japan (2008) & $\begin{array}{l}\text { "Reforming the tax system } \\
\text { to promote fiscal } \\
\text { sustainability and } \\
\text { economic growth" }\end{array}$ & $\begin{array}{l}\text { - Boost consumption tax rate above its } 5 \% \text { level and maintain single } \\
\text { rate } \\
\text { - } \text { Reduce statutory corporate tax rate by phasing out local corporate } \\
\text { tax } \\
\text { - Broaden corporate tax base, including by extending tax to exempted } \\
\text { firms } \\
\text { - Broaden personal income tax base and reform allowances and } \\
\text { deductions to encourage secondary workers to work longer hours, } \\
\text { - Ind reduce exemptions benefiting upper income taxpayers } \\
\text { - Strengthen property taxation, including of inheritances }\end{array}$ \\
\hline Korea (2008) & $\begin{array}{l}\text { "Reforming the tax system } \\
\text { to promote economic } \\
\text { growth and cope rapid } \\
\text { population ageing" }\end{array}$ & $\begin{array}{l}\text { - Lower statutory corporate tax rate and broaden the tax base } \\
\text { - Broaden tax base (including taxing fringe benefits) but expand the } \\
\text { earned-income tax credit and cut statutory rates } \\
\text { - Increase VAT rate and maintain unified rate, phasing out individual } \\
\text { consumption taxes } \\
\text { - Increase local property taxes while reducing transactions taxes }\end{array}$ \\
\hline
\end{tabular}


Table A1. Tax reform recommendations in OECD Economic Surveys (cont.)

\begin{tabular}{|c|c|c|}
\hline $\begin{array}{l}\text { Norway } \\
(2012)\end{array}$ & $\begin{array}{l}\text { "Tax reform in Norway: a } \\
\text { focus on capital taxation" }\end{array}$ & $\begin{array}{l}\text { - Align effective tax rates across assets } \\
\text { - Introduce tax on imputed rental income of owner-occupied housing } \\
\text { or a national property tax and/or phase out mortgage interest } \\
\text { deduction } \\
\text { - Abolish stamp duty on real estate transactions }\end{array}$ \\
\hline $\begin{array}{l}\text { Poland } \\
(2008)\end{array}$ & $\begin{array}{l}\text { "Reforming the tax system } \\
\text { to improve efficiency" }\end{array}$ & $\begin{array}{l}\text { - } \text { Further reduce tax wedge on labour by lowering social security } \\
\text { contributions for low-income earners } \\
\text { - } \text { Reduce bias in favour of self-employed } \\
\text { - } \text { Consider introducing an earned-income tax credit } \\
\text { - Eliminate tax allowances to enable reduced statutory personal } \\
\text { income tax rates } \\
\text { - Consider further reductions in the corporate income tax rate } \\
\text { - Consider introducing a carbon tax } \\
\text { - Replace current residential property tax with ad valorem system and } \\
\text { reduce transfers to municipalities to incite increase in property } \\
\text { taxation }\end{array}$ \\
\hline $\begin{array}{l}\text { Portugal } \\
(2010)\end{array}$ & $\begin{array}{l}\text { "Toward a less distortive } \\
\text { and more efficient tax } \\
\text { system" }\end{array}$ & $\begin{array}{l}\text { - Target cuts in social security contributions to low-income workers } \\
\text { - Integrate bases of labour income tax and social security } \\
\text { contributions } \\
\text { - Limit immovable property transactions tax to initial transaction } \\
\text { - Broaden personal income tax base by eliminating or reducing } \\
\text { credits for health care, mortgage interest payments and education } \\
\text { - Tax imputed rental income of owner-occupied housing } \\
\text { - Streamline corporate income tax provisions and broaden base } \\
\text { - Consider statutory reducing corporate tax rate } \\
\text { - Substantially extend scope of standard VAT rate, offsetting } \\
\text { regressive impact with enhanced income support for poor } \\
\text { households }\end{array}$ \\
\hline $\begin{array}{l}\text { Sweden } \\
(2008 \text { and } \\
2012)\end{array}$ & $\begin{array}{l}\text { "Housing, financial and } \\
\text { capital taxation policies to } \\
\text { ensure robust growth" } \\
\text { "Taxation and growth: } \\
\text { what direction should } \\
\text { Sweden take?" }\end{array}$ & $\begin{array}{l}\text { - Continue reductions of corporate income tax rate } \\
\text { - Continue cutting taxation of income from work, reducing high } \\
\text { - } \text { marginal tax wedge that sets in just above average earnings } \\
\text { - Constate housing tax levied in proportion to home value } \\
\text { - } \text { Move toward more neutral taxation across capital assets, especially } \\
\text { - } \text { taxing owner-occupied housing similarly to other assets } \\
\text { - Continue phasing out exemptions to carbon tax }\end{array}$ \\
\hline $\begin{array}{l}\text { Switzerland } \\
(2012)\end{array}$ & $\begin{array}{l}\text { "Making the tax system } \\
\text { less distortive" }\end{array}$ & $\begin{array}{l}\text { - Limit tax deductibility of mortgage interest to prevent its excess over } \\
\text { imputed rental income } \\
\text { - Remove marriage penalty at federal level by introducing individual } \\
\text { taxation } \\
\text { - Shift tax mix away from labour towards consumption taxes } \\
\text { - Allow local governments to raise real estate taxes to offset } \\
\text { - } \text { Implemment CO2 levy on transport fuels }\end{array}$ \\
\hline Turkey (2008) & $\begin{array}{l}\text { "Tax reform challenges" in } \\
\text { "Shifting to a pro-growth } \\
\text { fiscal strategy" }\end{array}$ & $\begin{array}{l}\text { - Significantly reduce social security contributions } \\
\text { - Close blatant tax loopholes and strengthen enforcement of both } \\
\text { direct taxes and VAT and generally improve tax administration } \\
\text { - } \quad \text { Consider extending VAT base } \\
\text { - Prepare timetable for eliminating tax expenditures }\end{array}$ \\
\hline
\end{tabular}

Source: Various OECD Economic Surveys, 2008-20, www.oecd-ilibrary.org/economics/oecd-economic-surveys 16097513. 
Table A2. Change in tax mix

$1995-2015$

\begin{tabular}{|c|c|c|c|c|c|c|c|c|c|c|c|c|c|}
\hline & $\begin{array}{c}\text { Total tax } \\
\text { revenue as a } \\
\% \text { of GDP in }\end{array}$ & & As a pe & cent of to & I tax reven & 1e in 2015 & & & ange in & re of to & tax revenu & $1995-2$ & \\
\hline & & PIT & SSC & CIT & Property & Cons & Other & PIT & SSC & CIT & Property & Cons & Other \\
\hline Australia & 28.2 & 41.5 & 0.0 & 15.3 & 10.7 & 27.5 & 5.0 & 0.8 & 0.0 & 0.5 & 1.9 & -1.5 & -1.8 \\
\hline Austria & 43.7 & 24.1 & 33.6 & 5.2 & 1.3 & 27.3 & 8.4 & 3.4 & -2.0 & 1.9 & -0.2 & -1.7 & -1.4 \\
\hline Belgium & 44.8 & 28.3 & 31.9 & 7.4 & 7.8 & 23.8 & 0.8 & -4.3 & -0.9 & 2.0 & 4.0 & -1.5 & 0.7 \\
\hline Canada & 32.0 & 36.9 & 15.1 & 9.9 & 11.8 & 23.1 & 3.2 & -0.7 & 1.1 & 1.7 & 1.2 & -2.3 & -1.0 \\
\hline Chile & 20.5 & 9.8 & 6.9 & 21.0 & 4.4 & 54.1 & 3.8 & 4.6 & 0.4 & 5.5 & -1.9 & -8.5 & -0.2 \\
\hline Crech Republic & 33.3 & 10.7 & 43.0 & 10.8 & 1.4 & 33.5 & 0.5 & -2.0 & 1.7 & -1.4 & 0.0 & 1.3 & 0.4 \\
\hline Denmark & 45.9 & 55.1 & 0.1 & 5.6 & 4.1 & 31.6 & 3.4 & 0.4 & 0.0 & 0.7 & 0.6 & -1.2 & -0.5 \\
\hline Estonia & 33.9 & 17.2 & 33.4 & 6.2 & 0.8 & 41.8 & 0.5 & -6.1 & -0.6 & -0.5 & -0.2 & 6.8 & 0.5 \\
\hline Finland & 43.9 & 30.2 & 28.9 & 4.9 & 3.3 & 32.4 & 0.3 & -0.9 & -1.9 & -0.1 & 1.1 & 1.8 & 0.1 \\
\hline France & 45.2 & 18.9 & 37.1 & 4.6 & 9.0 & 24.3 & 6.1 & 7.5 & -5.8 & -0.2 & 2.3 & -3.4 & -0.2 \\
\hline Gernany & 37.1 & 26.5 & 37.6 & 4.7 & 2.9 & 27.8 & 0.5 & -0.9 & -1.3 & 1.9 & 0.1 & -0.2 & 0.5 \\
\hline Greece & 36.4 & 15.0 & 29.4 & 5.9 & 8.5 & 39.4 & 1.8 & 3.0 & -3.0 & -0.4 & 4.4 & -1.9 & -2.1 \\
\hline Hungary & 39.0 & 13.7 & 32.4 & 4.6 & 3.3 & 43.8 & 2.2 & -2.4 & -3.3 & 0.2 & 2.1 & 3.1 & 0.3 \\
\hline Iceland & 36.7 & 36.7 & 9.8 & 6.5 & 5.4 & 32.4 & 9.3 & 5.6 & 1.7 & 3.5 & -3.7 & -16.3 & 9.3 \\
\hline Ireland & 23.1 & 31.6 & 16.8 & 11.3 & 6.4 & 32.6 & 1.2 & -0.3 & 3.3 & 3.0 & 1.9 & -7.8 & 0.0 \\
\hline Israel & 31.3 & 19.4 & 16.4 & 9.5 & 10.6 & 38.0 & 6.1 & -7.1 & 2.4 & 1.6 & 0.8 & 1.5 & 0.9 \\
\hline Italy & 43.3 & 26.0 & 30.1 & 4.7 & 6.5 & 27.3 & 5.4 & 0.0 & -1.4 & -4.0 & 0.8 & 0.0 & 4.5 \\
\hline Japan & 30.7 & 18.9 & 39.4 & 12.3 & 8.2 & 21.0 & 0.3 & -3.5 & 5.9 & -3.6 & -4.0 & 5.2 & 0.0 \\
\hline Korea & 25.2 & 17.2 & 26.6 & 13.1 & 12.4 & 28.0 & 2.7 & -0.9 & 14.5 & 1.5 & -1.6 & -12.7 & -0.7 \\
\hline Latvia & 29.0 & 20.4 & 28.7 & 5.5 & 3.4 & 41.3 & 0.6 & 4.1 & -8.2 & -0.1 & 0.0 & 3.6 & 0.6 \\
\hline Luxembourg & 36.8 & 24.5 & 29.0 & 11.9 & 8.9 & 25.5 & 0.3 & 2.4 & 2.0 & -6.1 & 1.8 & -0.2 & 0.1 \\
\hline Netherlands & 37.4 & 20.5 & 37.8 & 7.2 & 3.8 & 29.6 & 1.0 & 1.3 & -1.8 & -0.9 & -0.4 & 1.1 & 0.6 \\
\hline New Zealand & 33.0 & 38.1 & 0.0 & 13.8 & 6.1 & 38.4 & 3.6 & -6.9 & 0.0 & 1.9 & 0.7 & 5.0 & -0.7 \\
\hline Norway & 38.3 & 27.9 & 27.3 & 11.5 & 2.9 & 30.4 & 0.0 & 2.0 & 3.8 & 2.2 & 0.1 & -8.2 & 0.0 \\
\hline Poland & 32.4 & 14.4 & 38.5 & 5.7 & 4.2 & 35.9 & 1.3 & -7.4 & 8.7 & -1.5 & 0.9 & -1.0 & 0.4 \\
\hline Portugal & 34.6 & 21.2 & 26.1 & 9.0 & 3.7 & 38.4 & 1.6 & 2.6 & -0.1 & 1.3 & 0.5 & -4.7 & 0.4 \\
\hline Slovak Republic & 32.3 & 9.7 & 42.7 & 11.5 & 1.3 & 33.7 & 1.1 & 0.8 & 5.5 & -3.5 & -0.1 & -2.0 & -0.6 \\
\hline Sloveniz & 36.6 & 14.0 & 39.7 & 4.0 & 1.7 & 40.0 & 0.5 & -1.0 & -3.1 & 2.7 & 0.3 & 1.3 & -0.2 \\
\hline Spain & 33.8 & 21.3 & 33.8 & 7.0 & 7.7 & 29.7 & 0.5 & -2.3 & -2.3 & 1.3 & 2.1 & 0.6 & 0.5 \\
\hline Sweden & 43.3 & 29.1 & 22.4 & 6.9 & 2.4 & 28.1 & 11.1 & -4.4 & -5.3 & 1.1 & -0.3 & 0.0 & 8.9 \\
\hline Switzerland & 27.7 & 31.1 & 24.6 & 10.8 & 6.7 & 21.8 & 5.0 & -2.8 & -2.4 & 4.1 & -0.8 & 0.3 & 1.6 \\
\hline Turkey & 25.1 & 14.6 & 29.0 & 5.7 & 4.9 & 44.3 & 1.5 & -7.0 & 16.9 & -1.1 & 1.8 & 6.7 & -17.5 \\
\hline Unived Kingdom & 32.5 & 27.7 & 18.7 & 7.5 & 12.6 & 32.9 & 0.5 & -1.1 & 0.9 & -0.5 & 2.5 & -2.3 & 0.5 \\
\hline United States & 26.2 & 40.5 & 23.7 & 8.5 & 10.3 & 17.0 & 0.0 & 4.2 & -1.5 & -0.7 & -0.9 & -1.1 & 0.0 \\
\hline
\end{tabular}

Source: OECD (2017), Revenue Statistics: 1965-2016, OECD Publishing, Paris, https://doi.org/10.1787/9789264283183-en. 
Table A3. VAT rates and revenue ratios

\begin{tabular}{|c|c|c|c|c|}
\hline & $\begin{array}{c}\text { Standard VAT } \\
\text { rate in } 2014\end{array}$ & Reduced rates & $\begin{array}{l}\text { Average: } \\
\text { 2005-09 }\end{array}$ & $\begin{array}{l}\text { Average: } \\
2010-14\end{array}$ \\
\hline Australia & 10.0 & 0.0 & 0.53 & 0.49 \\
\hline Austria & 20.0 & 10.3/13.0 & 0.58 & 0.59 \\
\hline Belgium & 21.0 & $0.0 / 6.0 / 12.0$ & 0.49 & 0.48 \\
\hline Canada & 5.0 & 0.0 & 0.49 & 0.48 \\
\hline Chile & 19.0 & - & 0.65 & 0.63 \\
\hline Czech Republic & 21.0 & $10.0 / 15.0$ & 0.55 & 0.56 \\
\hline Denmark & 25.0 & 0.0 & 0.62 & 0.58 \\
\hline Estonia & 20.0 & $0.0 / 9.0$ & 0.74 & 0.68 \\
\hline Finland & 24.0 & $0.0 / 10.0 / 14.0$ & 0.59 & 0.55 \\
\hline France & 20.0 & $2.1 / 5.5 / 10.0$ & 0.50 & 0.48 \\
\hline Germany & 19.0 & 7.0 & 0.55 & 0.55 \\
\hline Greece & 23.0 & $6.0 / 13.0$ & 0.45 & 0.38 \\
\hline Hungary & 27.0 & $5.0 / 18.0$ & 0.56 & 0.53 \\
\hline Iceland & 25.5 & $0.0 / 11.0$ & 0.57 & 0.45 \\
\hline Ireland & 23.0 & $0.0 / 4.8 / 9.0 / 13.5$ & 0.59 & 0.46 \\
\hline Israel & 18.0 & 0.0 & 0.63 & 0.65 \\
\hline Italy & 22.0 & $4.0 / 5.0 / 10.0$ & 0.39 & 0.38 \\
\hline Japan & 5.0 & - & 0.69 & 0.70 \\
\hline Korea & 10.0 & 0.0 & 0.64 & 0.68 \\
\hline Latvia & 21,0 & $0.0 / 12.0$ & 0.53 & 0.46 \\
\hline Luxembourg & 15.0 & $3.0 / 8.0 / 14.0$ & 0.92 & 1.12 \\
\hline Mexico & 16.0 & 0.0 & 0.32 & 0.31 \\
\hline Netherlands & 21.0 & 6.0 & 0.57 & 0.51 \\
\hline New Zealand & 15.0 & 0.0 & 0.99 & 0.98 \\
\hline Norway & 25.0 & $0.0 / 10.0 / 15.0$ & 0.58 & 0.56 \\
\hline Poland & 23.0 & $5.0 / 8.0$ & 0.49 & 0.45 \\
\hline Portugal & 23.0 & $6.0 / 13.0$ & 0.50 & 0.47 \\
\hline Slovak Republic & 20.0 & 10.0 & 0.54 & 0.46 \\
\hline Slovenia & 22.0 & 9.5 & 0.66 & 0.60 \\
\hline Spain & 21.0 & $4.0 / 10.0$ & 0.48 & 0.41 \\
\hline Sweden & 25.0 & $0.0 / 6.0 / 12.0$ & 0.57 & 0.57 \\
\hline Switzerland & 8.0 & $0.0 / 2.5 / 3.8$ & 0.73 & 0.71 \\
\hline Turkey & 18.0 & $1.0 / 8.0$ & 0.36 & 0.42 \\
\hline United Kingdom & 20.0 & $0.0 / 5.0$ & 0.43 & 0.43 \\
\hline Unweighted average & 19.1 & & 0.57 & 0.55 \\
\hline
\end{tabular}

Source: OECD (2016), Consumption Tax Trends 2016: VAT/GST and Excise Rates, Trends and Policy Issues, OECD Publishing Paris, https://doi.org/10.1787/ctt-2016-en. 